Article

\title{
Transition Metal Complexes Coordinated by Water Soluble Phosphane Ligands: How Cyclodextrins Can Alter the Coordination Sphere?
}

\author{
Michel Ferreira, Hervé Bricout, Sébastien Tilloy and Eric Monflier* \\ University of Artois, CNRS, Centrale Lille, ENSCL, University of Lille, UMR 8181, \\ Unité de Catalyse et de Chimie du Solide (UCCS), F-62300 Lens, France; michel.ferreira@univ-artois.fr (M.F.); \\ herve.bricout@univ-artois.fr (H.B.); sebastien.tilloy@univ-artois.fr (S.T.) \\ * Correspondence: eric.monflier@univ-artois.fr; Tel.: +33-321-791-772; Fax: +33-321-791-717 \\ Academic Editor: Bernard Martel
}

Received: 9 December 2016; Accepted: 12 January 2017; Published: 17 January 2017

\begin{abstract}
The behaviour of platinum(II) and palladium(0) complexes coordinated by various hydrosoluble monodentate phosphane ligands has been investigated by ${ }^{31} \mathrm{P}\left\{{ }^{1} \mathrm{H}\right\} \mathrm{NMR}$ spectroscopy in the presence of randomly methylated $\beta$-cyclodextrin (RAME- $\beta-C D)$. This molecular receptor can have no impact on the organometallic complexes, induce the formation of phosphane low-coordinated complexes or form coordination second sphere species. These three behaviours are under thermodynamic control and are governed not only by the affinity of RAME- $\beta-C D$ for the phosphane but also by the phosphane stereoelectronic properties. When observed, the low-coordinated complexes may be formed either via a preliminary decoordination of the phosphane followed by a complexation of the free ligand by the $\mathrm{CD}$ or via the generation of organometallic species complexed by $\mathrm{CD}$ which then lead to expulsion of ligands to decrease their internal steric hindrance.
\end{abstract}

Keywords: platinum; palladium; TPPTS; cyclodextrin; hydrosoluble organometallic complexes; supramolecular chemistry

\section{Introduction}

Biphasic aqueous organometallic catalysis is one of the greenest solutions to produce organic chemicals [1,2]. Indeed, water is not only cheap and non-toxic, but also permits one to immobilize the catalyst in an aqueous phase by the use of water-soluble ligands, leading to ease of recycling by simple decantation at the end of the reaction [3]. The most widespread ligand used in such systems is TPPTS (tris(3-sulfonatophenyl)phosphane sodium salt, Table 1, entry 1) which is responsible for the industrial success of the aqueous biphasic propene hydroformylation (Ruhrchemie-Rhône Poulenc process, 1984) [4]. Attractive for partially water-soluble olefins, this strategy suffers from low catalytic activity when hydrophobic substrates are used due to mass transfer limitations. The alternative approaches to overcome this drawback have been recently reviewed $[5,6]$. These include the use of cyclodextrins (CDs) which are widely recognized as outstanding water-soluble receptors in aqueous biphasic organometallic processes [7].

These macrocycles were firstly used as phase transfer agents between the organic and the aqueous layers by forming inclusion complexes with a hydrophobic substrate at the interface in order to convert it thanks to a water-soluble organometallic catalyst. However, CDs are more than simple receptors for hydrophobic substrates and can be now considered as polyfunctional entities in aqueous biphasic organometallic catalysis [8]. In particular, CDs can modify the catalytic species involved in the reaction. As an example, when TPPTS is combined with a rhodium precursor to catalyse the 1-decene aqueous biphasic hydroformylation reaction, a linear to branched aldehyde ratio drop is 
observed when the experiment is conducted in the presence of RAME- $\beta-C D$ (=randomly methylated $\beta-C D)$ [9]. Under $\mathrm{CO} / \mathrm{H}_{2}$ pressure and with $\mathrm{RAME}-\beta-\mathrm{CD}$, equilibria displacements between the different catalytic species towards the formation of phosphane low-coordinated species are observed. These equilibria, displaced by TPPTS inclusion into the CD cavity, are responsible for the drop in regioselectivity (Scheme 1) [10].

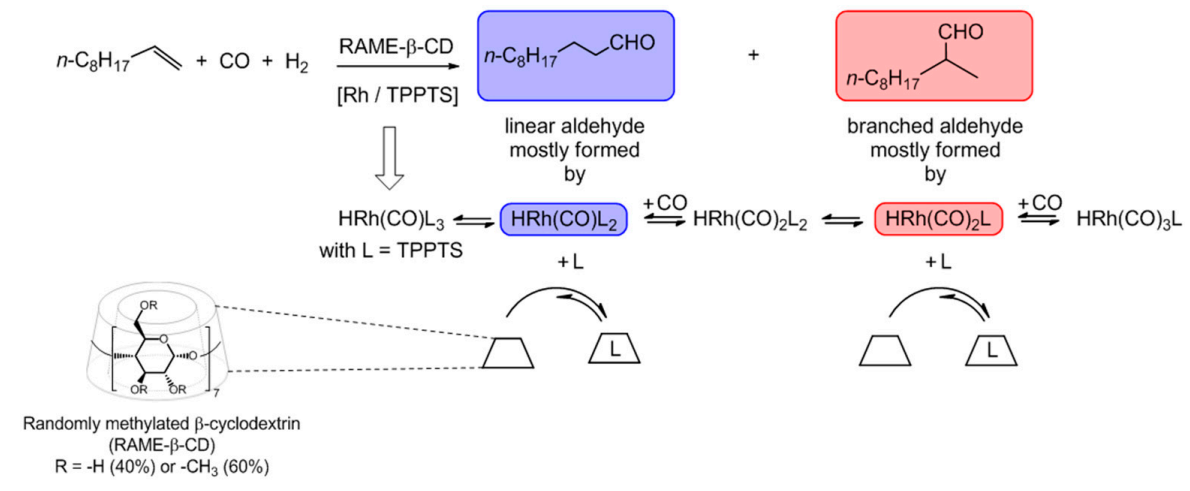

Scheme 1. Equilibria between the different catalytic species during 1-decene aqueous biphasic hydroformylation assisted by RAME- $\beta-C D$.

Along the same lines, when a water-soluble triphenylphosphane derivative possessing a higher affinity towards CDs is involved in a rhodium $\mathrm{HRhCOL}_{3}$ type species $\left(\mathrm{L}=p\right.$-tBuPhP $\left(m-\mathrm{PhSO} \mathrm{Na}_{2}\right.$ phosphane), unsaturated catalytic species are also formed in the presence of $\mathrm{CD}$ even when the organometallic complex was not exposed to a $\mathrm{CO} / \mathrm{H}_{2}$ atmosphere [11].

This behaviour, not observed with TPPTS, was attributed to the more stable inclusion complex formed between the CD and the phosphane, due to the presence of the well-recognized p-tert-butylphenyl group. Moreover, it has been demonstrated that the combination of the same ligand with another metal centre, e.g., palladium or platinum, led to the same behaviour, that is to say formation of low-coordinated organometallic species [12].

However, the combination of a palladium precursor with a water-soluble triphenylphosphane derivative possessing a $p$-tert-butylbiphenyl group led to the formation of a stable second-sphere coordination adduct where the CD encapsulated the ligand directly bounded to the metal centre [13]. Such species had already been observed with a phosphane bearing adamantyl groups [14].

Table 1. Structure, abbreviation of the water-soluble phosphanes used, and value of the association constant $(\mathrm{K})$ for the inclusion complexes between the RAME- $\beta-\mathrm{CD}$ and the phosphane.

\begin{tabular}{|c|c|c|c|}
\hline Entry & Structure & Name Abbreviation & $K\left(M^{-1}\right)^{a, b}$ \\
\hline 1 & & $\begin{array}{l}\text { tris(3-sodium-sulfonatophenyl)phosphane } \\
\text { TPPTS }\end{array}$ & 840 [15] \\
\hline 2 & & $\begin{array}{l}\text { tris(4-methyl-3-sodium-sulfonatophenyl)phosphane } \\
\text { tris }(p-\mathrm{Me}) \text { TPPTS }\end{array}$ & 960 [15] \\
\hline 3 & & $\begin{array}{l}\text { tris(4-methoxy-3-sodium-sulfonatophenyl)phosphane } \\
\text { tris }(p \text {-OMe)TPPTS }\end{array}$ & $0[15]$ \\
\hline 4 & & $\begin{array}{l}\text { tris(6-methyl-3-sodium-sulfonatophenyl)phosphane } \\
\text { tris }(o-\mathrm{Me}) \mathrm{TPPTS}\end{array}$ & $0[15]$ \\
\hline 5 & $\mathrm{P}(\underbrace{-\mathrm{SO}_{3}}_{\mathrm{MeO}}$ & $\begin{array}{l}\text { tris(6-methoxy-3-sodium-sulfonatophenyl)phosphane } \\
\text { tris }(o-\mathrm{OMe}) \mathrm{TPPTS}\end{array}$ & $0[15]$ \\
\hline
\end{tabular}


Table 1. Cont.

\begin{tabular}{|c|c|c|c|}
\hline Entry & Structure & Name Abbreviation & $K\left(M^{-1}\right)^{a, b}$ \\
\hline 6 & & $\begin{array}{l}\text { trisulfonated monobiphenyldiphenylphosphane } \\
\qquad \mathrm{P}(\mathrm{Biph}) \mathrm{Ph}_{2} \mathrm{TS}\end{array}$ & $9900^{c}$ \\
\hline 7 & & $\begin{array}{l}\text { trisulfonated bisbiphenylmonophenylphosphane } \\
\qquad \mathrm{P}(\mathrm{Biph})_{2} \mathrm{PhTS}\end{array}$ & $>100,000^{c}$ \\
\hline 8 & & $\begin{array}{l}\text { trisulfonated trisbiphenylphosphane } \\
\text { P(Biph })_{3} T S\end{array}$ & $>100,000^{c}$ \\
\hline
\end{tabular}

In order to get a better insight into the interaction phenomena between the $\mathrm{CD}$ and transition metal complexes, we want to show in this article how RAME- $\beta$-CD can interfere with different platinum(II) or palladium(0) complexes coordinated with various hydrosoluble ligands and how specific organometallic complexes can be obtained. These ligands include TPPTS itself but also TPPTS modified phosphanes containing substituents (methyl or methoxy groups) in ortho or para position and biphenyl modified phosphanes (Table 1). The interaction of the different phosphanes with RAME- $\beta-C D$ has already been studied by our group [15], except for biphenylphosphane derivatives whose synthesis and catalytic properties have been exclusively published [16]. For each type of ligands, we have both examined the nature of the organometallic complex formed when mixing them with the metal precursor and the influence of the RAME- $\beta-C D$ addition on these complexes.

\section{Results and Discussion}

\subsection{Platinum Complexes}

The different complexes formed by mixing the $\mathrm{K}_{2} \mathrm{PtCl}_{4}$ aqueous solution with 3 equiv. of phosphane were firstly analysed by ${ }^{31} \mathrm{P}\left\{{ }^{1} \mathrm{H}\right\}$ NMR. In a second step, RAME- $\beta$-CD has been added to the mixture in order to determine its influence on the coordination chemistry of the different ligands.

\subsubsection{Complex Synthesis}

\section{TPPTS Ligand}

As described in the literature [17], [Pt(TPPTS) $\left.{ }_{3} \mathrm{Cl}\right] \mathrm{Cl}$ platinum complex is quantitatively synthetized by adding three equivalents of TPPTS to a $\mathrm{K}_{2} \mathrm{PtCl}_{4}$ aqueous solution. As only one third of the platinum $\left({ }^{195} \mathrm{Pt}\right)$ has a spin of $1 / 2$, the ${ }^{31} \mathrm{P}\left\{{ }^{1} \mathrm{H}\right\}$ NMR spectrum of this complex is characterized by a 1:4:1 triplet of doublets centred at $\delta=24.5 \mathrm{ppm}\left({ }^{1} \mathrm{PP}_{c i s}-\mathrm{Pt}=2491 \mathrm{~Hz} ;{ }^{2} J \mathrm{P}_{\text {cis }}-\mathrm{P}_{\text {trans }}=19 \mathrm{~Hz}\right)$ corresponding to the two phosphorus atoms cis to the chloride and a 1:4:1 triplet of triplets centred at $\delta=13.3 \mathrm{ppm}\left({ }^{1} \mathrm{JP}_{\text {trans }}-\mathrm{Pt}=3682 \mathrm{~Hz} ;{ }^{2} J \mathrm{P}_{\text {cis }}-\mathrm{P}_{\text {trans }}=19 \mathrm{~Hz}\right)$ corresponding to the phosphorus atom trans to the chloride (Figure 1).

\section{para-Substituted TPPTS Derivatives}

Similarly to TPPTS, $\left[\mathrm{PtL}_{3} \mathrm{Cl}\right] \mathrm{Cl}$ platinum complexes can be quantitatively synthetized by adding three equivalents of the para-substituted ligands tris( $p$-Me)TPPTS and tris( $p$-OMe)TPPTS to a solution of $\mathrm{K}_{2} \mathrm{PtCl}_{4}$ (Figure 2). The two phosphorus atoms cis to the chloride appear respectively for $\left[\mathrm{Pt}(\operatorname{tris}(p-\mathrm{Me}) \mathrm{TPPTS})_{3} \mathrm{Cl}\right] \mathrm{Cl}$ and $\left[\mathrm{Pt}(\operatorname{tris}(p-\mathrm{OMe}) \mathrm{TPPTS}){ }_{3} \mathrm{Cl}\right] \mathrm{Cl}$ at $\delta=23.3 \mathrm{ppm}\left({ }^{1} \mathrm{JP} \mathrm{cis}_{\text {cis }}-\mathrm{Pt}=2488 \mathrm{~Hz}\right.$; $\left.{ }^{2} J \mathrm{P}_{\text {cis }}-\mathrm{P}_{\text {trans }}=19 \mathrm{~Hz}\right)$ and $\delta=21.8 \mathrm{ppm}\left({ }^{1} J \mathrm{P}_{\text {cis }}-\mathrm{Pt}=2487 \mathrm{~Hz} ;{ }^{2} J \mathrm{P}_{\text {cis }}-\mathrm{P}_{\text {trans }}=18 \mathrm{~Hz}\right)$ in their ${ }^{31} \mathrm{P}\left\{{ }^{1} \mathrm{H}\right\} \mathrm{NMR}$ spectra. The phosphorus atom trans to the chloride appears at $\delta=11.5 \mathrm{ppm}\left({ }^{1} J \mathrm{P}_{\text {trans }}-\mathrm{Pt}=3693 \mathrm{~Hz}\right.$; $\left.{ }^{2} \mathrm{JP}_{\text {cis }}-\mathrm{P}_{\text {trans }}=19 \mathrm{~Hz}\right)$ and $\delta=9.8 \mathrm{ppm}\left({ }^{1} J \mathrm{P}_{\text {trans }}-\mathrm{Pt}=3754 \mathrm{~Hz} ;{ }^{2} J \mathrm{P}_{\text {cis }}-\mathrm{P}_{\text {trans }}=18 \mathrm{~Hz}\right)$. 

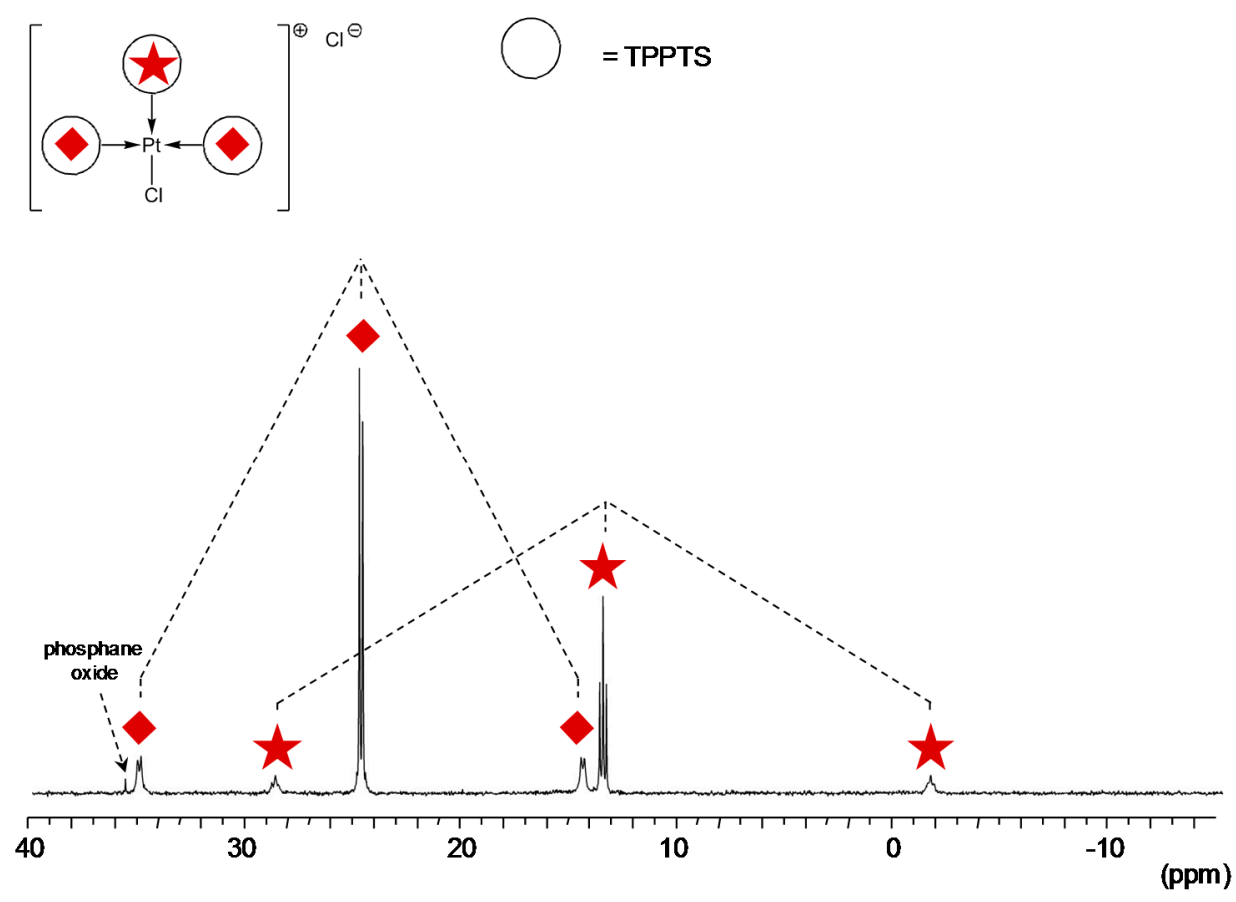

Figure $1 .{ }^{31} \mathrm{P}\left\{{ }^{1} \mathrm{H}\right\}$ NMR spectrum of $\left[\mathrm{Pt}(\mathrm{TPPTS}){ }_{3} \mathrm{Cl}\right] \mathrm{Cl},[\mathrm{Pt}]=10 \mathrm{mM}, 25{ }^{\circ} \mathrm{C}$ in $\mathrm{D}_{2} \mathrm{O}$.



Figure 2. ${ }^{31} \mathrm{P}\left\{{ }^{1} \mathrm{H}\right\}$ NMR spectra of (a) $\left[\mathrm{Pt}(\operatorname{tris}(p-\mathrm{Me}) \mathrm{TPPTS})_{3} \mathrm{Cl}\right] \mathrm{Cl}$ and $(\mathbf{b})\left[\mathrm{Pt}(\operatorname{tris}(p-\mathrm{OMe}) \mathrm{TPPTS})_{3} \mathrm{Cl}\right] \mathrm{Cl}$, $[\mathrm{Pt}]=10 \mathrm{mM}, 25^{\circ} \mathrm{C}$ in $\mathrm{D}_{2} \mathrm{O}$.

ortho-Substituted TPPTS Derivatives

However, attempts to synthetize $\left[\mathrm{Pt}(\operatorname{tris}(o-\mathrm{Me}) \mathrm{TPPTS})_{3} \mathrm{Cl}\right] \mathrm{Cl}$ and $\left[\mathrm{Pt}(\operatorname{tris}(o-\mathrm{OMe}) \mathrm{TPPTS})_{3} \mathrm{Cl}\right] \mathrm{Cl}$ were unsuccessful. Indeed, addition of three equivalents of ligand (towards platinum) to a 
$\mathrm{K}_{2} \mathrm{PtCl}_{4}$ solution exclusively yields to formation of $\mathrm{PtCl}_{2} \mathrm{~L}_{2}$-type complex characterized by a 1:4:1 triplet of doublets centred at $\delta=20.5 \mathrm{ppm}$ and $24.5 \mathrm{ppm}$, respectively, for $\mathrm{PtCl}_{2}(\operatorname{tris}(o-\mathrm{Me}) \mathrm{TPPTS})_{2}$ and $\mathrm{PtCl}_{2}(\operatorname{tris}(o-\mathrm{OMe}) \mathrm{TPPTS})_{2}$. As a consequence, free ligand that represents one third of the total ${ }^{31} \mathrm{P}\left\{{ }^{1} \mathrm{H}\right\}$ NMR surface area is detected (Figure 3). Moreover, in both cases, ${ }^{1} \mathrm{JP}-\mathrm{Pt}$ coupling constants (2750 and $2590 \mathrm{~Hz}$ for $\mathrm{PtCl}_{2}$ (tris(o-OMe)TPPTS $)_{2}$ and $\mathrm{PtCl}_{2}$ (tris(o-Me)TPPTS $)_{2}$ respectively) are consistent with a trans coordination when compared with cis- $\mathrm{PtCl}_{2}$ (TPPTS $)_{2}\left({ }^{1} \mathrm{JP}-\mathrm{Pt}=3720 \mathrm{~Hz}\right.$, Figure 4$)$ and trans $-\mathrm{PtCl}{ }_{2}(\mathrm{TPPTS})_{2}\left({ }^{1} \mathrm{JP}-\mathrm{Pt}=2600 \mathrm{~Hz}\right)$ that have already been described [17]. The steric hindrance of these ligands, which have a higher cone angle than their para-substituted counterparts, is obviously responsible for the formation of the observed phosphane low coordinated $\mathrm{PtCl}_{2} \mathrm{~L}_{2}$ species. The same reason can also explain the trans geometry obtained for these species instead of the cis one [18].

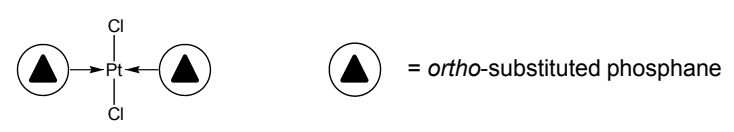

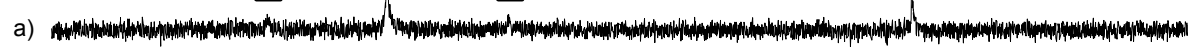
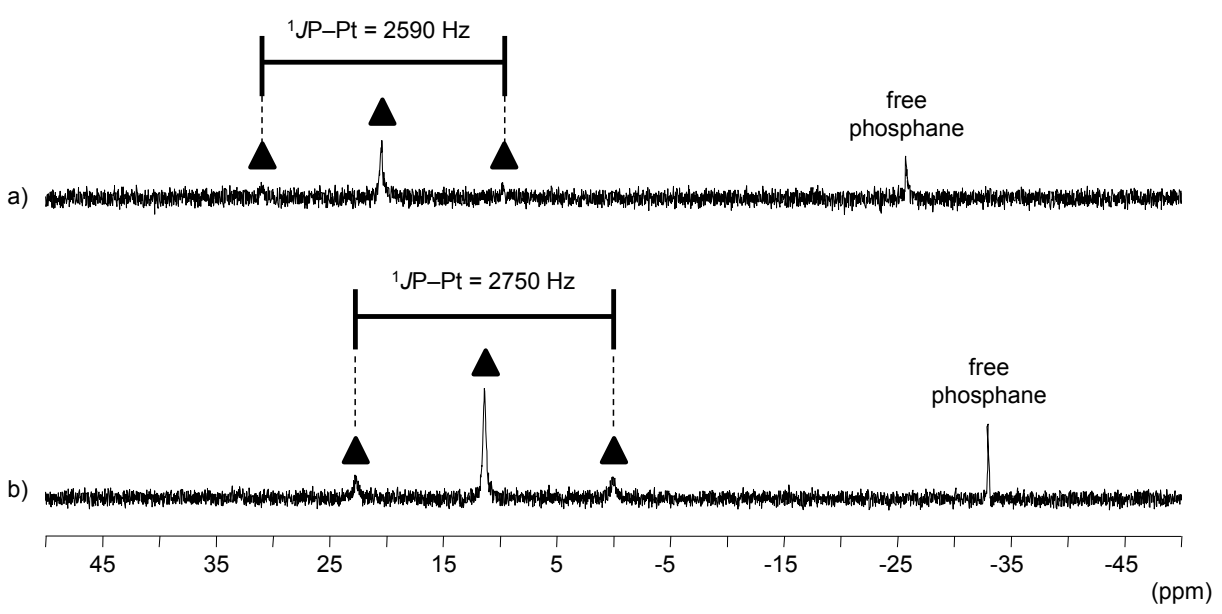

Figure 3. ${ }^{31} \mathrm{P}\left\{{ }^{1} \mathrm{H}\right\} \mathrm{NMR}$ spectra of $\mathrm{K}_{2} \mathrm{PtCl}_{4}(3 \mathrm{mM})+3$ equiv. of $(\mathbf{a})$ tris $(o-\mathrm{Me}) \mathrm{TPPTS}$ or $(\mathbf{b})$ tris $(o-\mathrm{OMe}) \operatorname{TPPTS}$ at $25^{\circ} \mathrm{C}$ in $\mathrm{D}_{2} \mathrm{O}$.
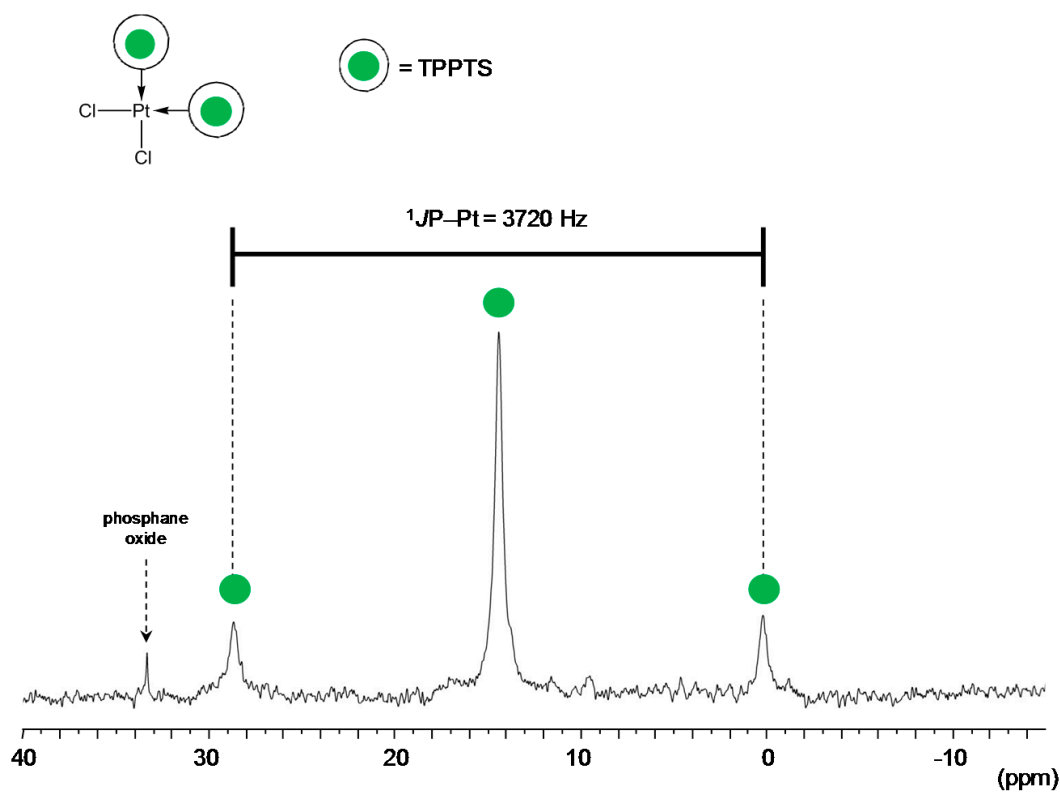

Figure 4. ${ }^{31} \mathrm{P}\left\{{ }^{1} \mathrm{H}\right\}$ NMR spectrum of cis- $\mathrm{PtCl}_{2}$ (TPPTS $)_{2},[\mathrm{Pt}]=10 \mathrm{mM}, 25^{\circ} \mathrm{C}$ in $\mathrm{D}_{2} \mathrm{O}$. 
Trisulfonated Biphenylphosphane Ligands

Again, $\left[\mathrm{PtL}_{3} \mathrm{Cl}\right] \mathrm{Cl}$ complex was obtained by adding three equivalents of the monobiphenyl ligand $\mathrm{P}(\mathrm{Biph}) \mathrm{Ph}_{2} \mathrm{TS}$ to a $\mathrm{K}_{2} \mathrm{PtCl}_{4}$ aqueous solution. However, when $\mathrm{P}(\mathrm{Biph})_{2} \mathrm{PhTS}$ and $\mathrm{P}(\mathrm{Biph})_{3} \mathrm{TS}$ were used, the complexes appeared as broad signals in the ${ }^{31} \mathrm{P}\left\{{ }^{1} \mathrm{H}\right\} \mathrm{NMR}$ spectra. Addition of DMSO to the previous aqueous solutions achieves finer signals (Figure 5).
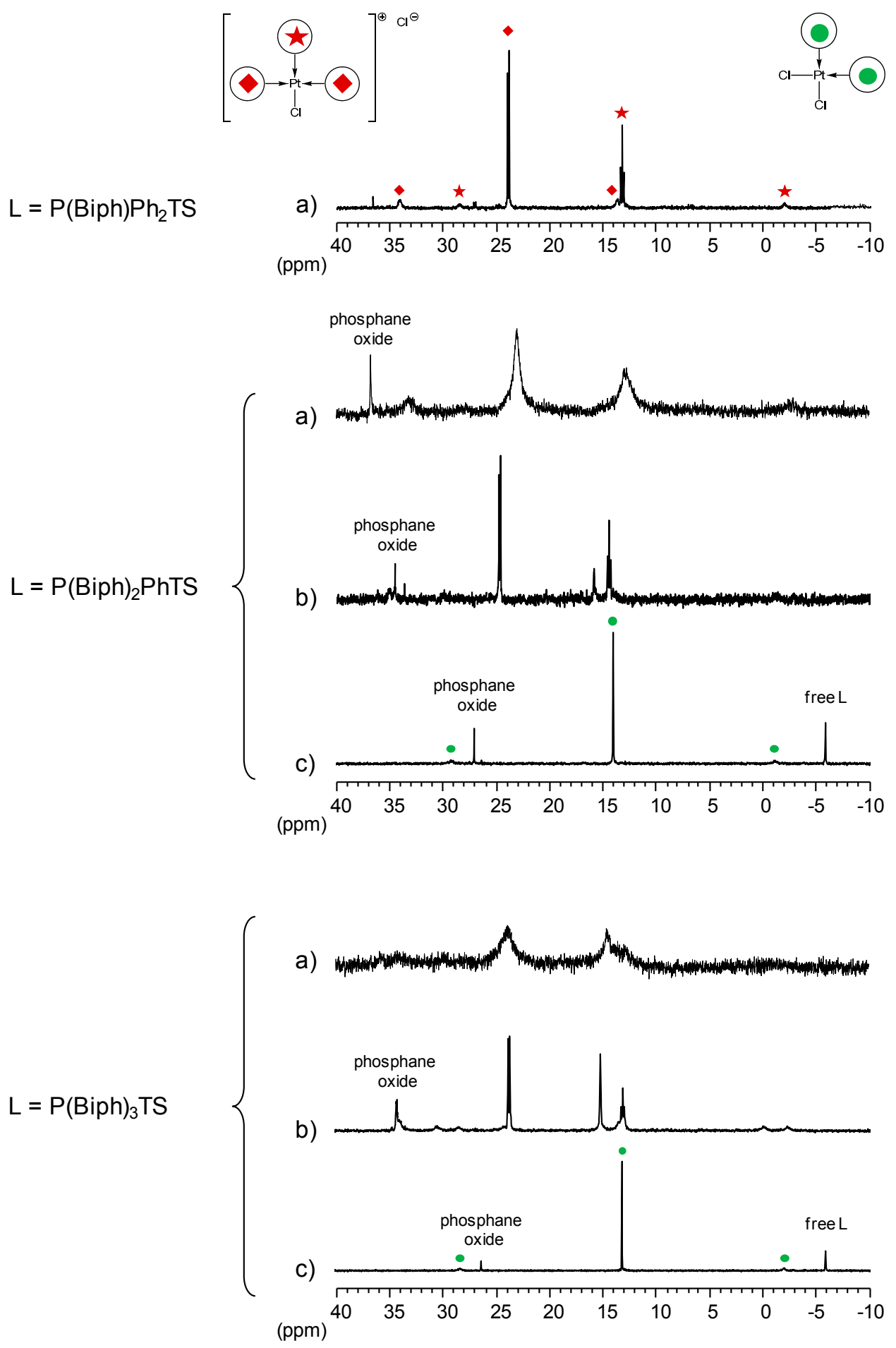

Figure $5 .{ }^{31} \mathrm{P}\left\{{ }^{1} \mathrm{H}\right\} \mathrm{NMR}$ spectra of $\mathrm{K}_{2} \mathrm{PtCl}_{4}$ solution $(10 \mathrm{mM})+3$ equiv. of ligand $(\mathrm{L})$ at $25^{\circ} \mathrm{C}(\mathbf{a})$ in $\mathrm{D}_{2} \mathrm{O}$ (b) in $\mathrm{D}_{2} \mathrm{O} /$ DMSO- $d_{6}$ mixture (50/50 vol.) (c) in DMSO- $d_{6}$. 
In pure DMSO, cis- $\mathrm{PtCl}_{2} \mathrm{~L}_{2}$ is formed quantitatively $\left({ }^{1} \mathrm{JP}-\mathrm{Pt}=3696 \mathrm{~Hz}\right.$ when $\mathrm{L}=\mathrm{P}(\mathrm{Biph}){ }_{2} \mathrm{PhTS}$ and ${ }^{1} \mathrm{JP}-\mathrm{Pt}=3702 \mathrm{~Hz}$ when $\left.\mathrm{L}=\mathrm{P}(\mathrm{Biph})_{3} \mathrm{TS}\right)$. The lowest $\mathrm{DMSO}$ polarity compared to water is probably responsible for the formation of these non-ionic complexes. When the water quantity of the medium is increased, the polarity increases as well probably leading to the formation of $\left[\mathrm{PtL}_{3} \mathrm{Cl}\right] \mathrm{Cl}$. With these two ligands, fast exchange between $\left[\mathrm{PtL}_{3} \mathrm{Cl}\right] \mathrm{Cl}$ complex and water molecules would be responsible for the signals broadening.

\subsubsection{RAME- $\beta$-CD Effects on the Coordination Behaviour of the Ligands}

As a reminder of our previous work, Table 1 brings together the association constants between the different hydrosoluble ligands studied and the CDs [15].

\section{TPPTS Ligand}

When 1equiv. of RAME- $\beta$-CD toward platinum was added to a solution of the [Pt(TPPTS $\left.)_{3} \mathrm{Cl}\right] \mathrm{Cl}$ complex, a downfield chemical shift of the TPPTS oxide signal was observed and attributed to the formation of an inclusion complex with RAME- $\beta$-CD [19]. Moreover, a typical signal of CD-included TPPTS appeared at $-8.8 \mathrm{ppm}$ as well as a cis- $\mathrm{PtCl}_{2}$ (TPPTS) $)_{2}$ signal at $15.5 \mathrm{ppm}$ (Figure 6).

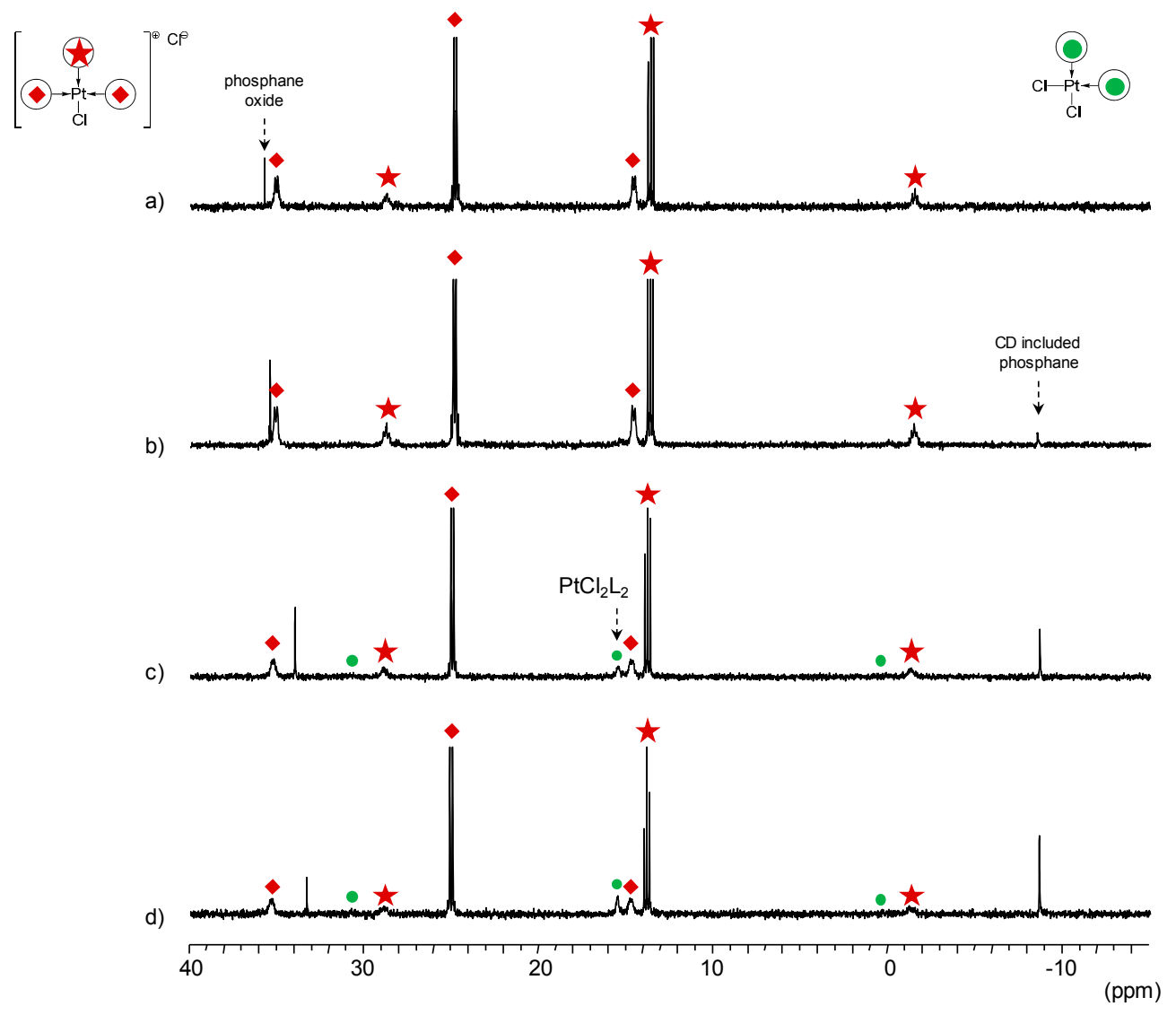

Figure 6. ${ }^{31} \mathrm{P}\left\{{ }^{1} \mathrm{H}\right\}$ NMR spectra of (a) [Pt(TPPTS $\left.)_{3} \mathrm{Cl}\right] \mathrm{Cl}(10 \mathrm{mM}) ;(\mathbf{b})+3$ equiv. of RAME- $\beta$-CD toward $\mathrm{Pt}(\mathbf{c})+6$ equiv. of RAME- $\beta-\mathrm{CD}$ and $(\mathbf{d})+12$ equiv. of RAME- $\beta-\mathrm{CD}$ at $25^{\circ} \mathrm{C}$ in $\mathrm{D}_{2} \mathrm{O}$.

By adding increasing amounts of CD (3 to 12 equiv.), these signals are intensified. Thus, RAME- $\beta$-CD is able to modify the equilibrium between these two organometallic species. In particular, the formation of phosphane low-coordinated organometallic species is favoured by the formation of an inclusion complex between RAME- $\beta$-CD and TPPTS as depicted in Scheme 2 (equilibrium (1) is displaced by equilibrium (2)). Note that such behaviour is similar to what is observed by high pressure NMR when RAME- $\beta-C D$ is added, under hydroformylation conditions ( 50 bars $\mathrm{CO} / \mathrm{H}_{2}$ and $80^{\circ} \mathrm{C}$ ), 
on the $\mathrm{HRh}(\mathrm{CO})(\mathrm{TPPTS})_{3}$ rhodium complex. In that case, $\mathrm{HRh}(\mathrm{CO})_{2}(\mathrm{TPPTS})_{2}$ species combined with TPPTS included in the CD cavity were highlighted [10].

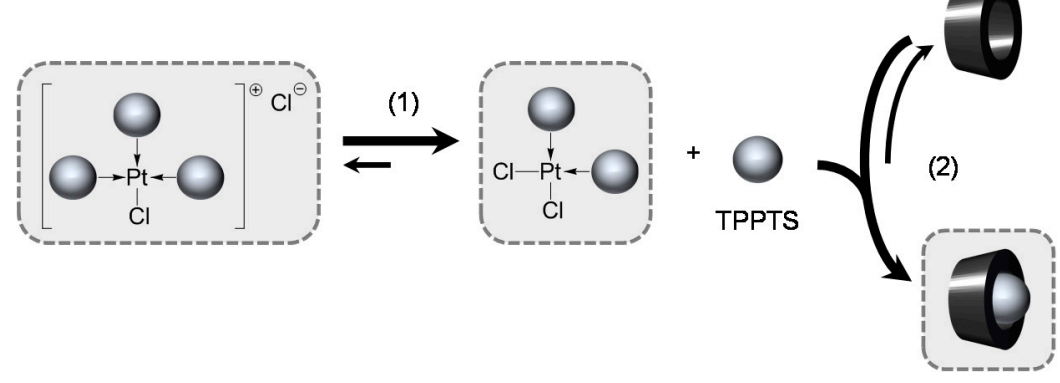

Scheme 2. Equilibria between the different platinum species with TPPTS as ligand in the presence of RAME- $\beta$-CD (species observed on the ${ }^{31} \mathrm{P}\left\{{ }^{1} \mathrm{H}\right\}$ NMR spectrum are presented on a grey background).

The conversion of $\left[\mathrm{Pt}(\mathrm{TPPTS})_{3} \mathrm{Cl}\right] \mathrm{Cl}$ into $c$ is $-\mathrm{PtCl}_{2}(\mathrm{TPPTS})_{2}$ as a function of the RAME- $\beta-\mathrm{CD}$ quantity (Figure 7) can be measured by integration of the ${ }^{31} \mathrm{P}\left\{{ }^{1} \mathrm{H}\right\}$ NMR spectra (see ESI). As expected, the conversion increases with the quantity of RAME- $\beta-C D$ in solution. The temperature also has an influence on these equilibria. Indeed, the conversion increases with the temperature, therefore, implying that the natural dissociation of TPPTS from $\left[\mathrm{Pt}(\mathrm{TPPTS})_{3} \mathrm{Cl}\right] \mathrm{Cl}$ is more affected compared to the inclusion complex stability. Moreover, the NMR spectrum carried out at room temperature after heating gave back the signals with the same initial intensity reflecting the process reversibility and assuming a thermodynamic control of the system.

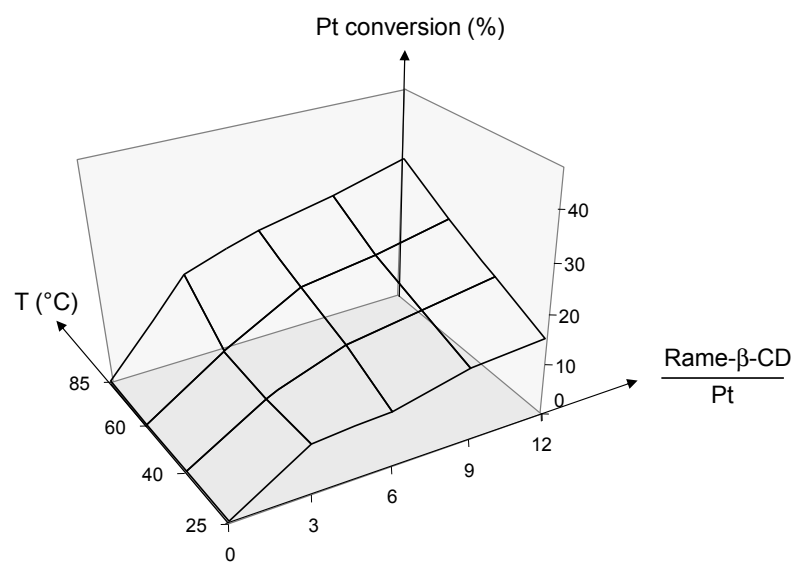

\begin{tabular}{|c|c|c|c|c|}
\hline $\mathrm{CD} / \mathrm{Pt}^{T\left({ }^{\circ} \mathrm{C}\right)}$ & 25 & 40 & 60 & 85 \\
\hline 0 & 0 & 0 & 0 & 0 \\
\hline 3 & 9.2 & 9.5 & 9.9 & 17.3 \\
\hline 6 & 10.4 & 14.7 & 18 & 22.0 \\
\hline 9 & 13.9 & 17.9 & 20.0 & 24.8 \\
\hline 12 & 14.7 & 18.8 & 23.1 & 28.4 \\
\hline
\end{tabular}

Figure 7. $\left[\mathrm{Pt}(\mathrm{TPPTS})_{3} \mathrm{Cl}\right] \mathrm{Cl}$ conversion (\%) into cis- $\mathrm{PtCl}_{2}(\mathrm{TPPTS})_{2}$ as a function of RAME- $\beta$-CD quantity and temperature, $[\mathrm{Pt}]=10 \mathrm{mM}, \mathrm{D}_{2} \mathrm{O}$.

para-Substituted TPPTS Derivatives

The behaviour of tris $(p$-OMe)TPPTS and tris $(p-\mathrm{Me})$ TPPTS towards RAME- $\beta$-CD is different. Indeed, unlike tris( $p$-OMe)TPPTS, tris $(p$-Me)TPPTS forms an inclusion complex with this CD $\left(\mathrm{K}=960 \mathrm{M}^{-1}\right)$ [15]. The highest association constant of this inclusion complex compared to the complex RAME- $\beta$-CD/TPPTS $\left(K=840 \mathrm{M}^{-1}\right)$ is due to the deep inclusion of the tris( $p$-Me)TPPTS via one of its aryl groups into the CD cavity [20].

Given that the tris $(p-\mathrm{OMe})$ TPPTS does not interact with RAME- $\beta-C D$, it is not surprising to see no modifications on the ${ }^{31} \mathrm{P}\left\{{ }^{1} \mathrm{H}\right\} \mathrm{NMR}$ spectrum of the $\left[\mathrm{Pt}(\operatorname{tris}(p-\mathrm{OMe}) \mathrm{TPPTS})_{3} \mathrm{Cl}\right] \mathrm{Cl}$ organometallic complex when the RAME- $\beta$-CD was added (see ESI). Surprisingly, the same behaviour was observed with the tris $(p-\mathrm{Me}) \mathrm{TPPTS}$ ligand. Indeed, although the association constant between RAME- $\beta-\mathrm{CD}$ 
and tris $(p-\mathrm{Me})$ TPPTS is higher than the one between RAME- $\beta-C D$ and TPPTS, no conversion of $\left[\mathrm{Pt}(\operatorname{tris}(p-\mathrm{Me}) \mathrm{TPPTS})_{3} \mathrm{Cl}\right] \mathrm{Cl}$ to $\mathrm{PtCl}_{2}$ (tris( $p$-Me)TPPTS $)_{2}$ was highlighted after the addition of RAME- $\beta-C D$, even at high temperature (see ESI) [21]. This result can be explained by the higher $\sigma$-donating strength of tris( $p$-Me)TPPTS ligand, compared to TPPTS. Consequently, the equilibrium (1) is shifted towards the formation of the high coordinated platinum species $\left[\mathrm{Pt}(\operatorname{tris}(p-\mathrm{Me}) \mathrm{TPPTS})_{3} \mathrm{Cl}\right] \mathrm{Cl}$ even in the presence of RAME- $\beta-C D$ (Scheme 3).

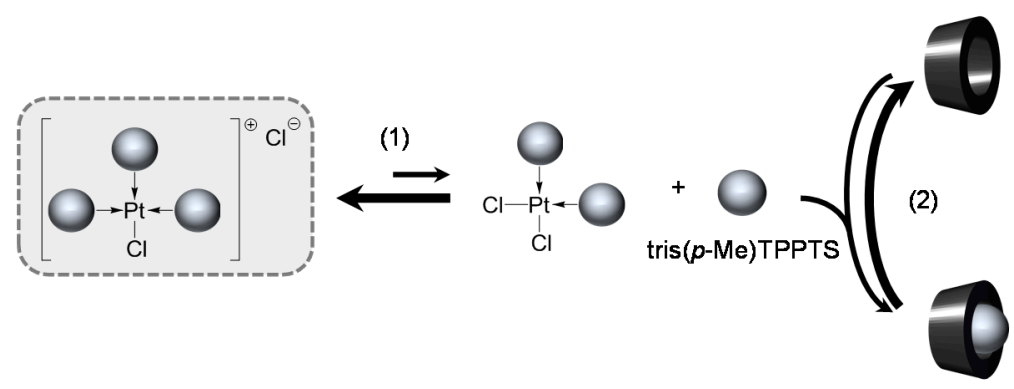

Scheme 3. Equilibria between the different platinum species with tris( $p$-Me)TPPTS as ligand in the presence of RAME- $\beta$-CD (species observed on the ${ }^{31} \mathrm{P}\left\{{ }^{1} \mathrm{H}\right\}$ NMR spectrum are presented on a grey background).

\section{Ortho-Substituted TPPTS Derivatives}

Since the ortho-substituted ligands do not interact with RAME- $\beta-C D[15,20]$, addition of CD did not modify the ${ }^{31} \mathrm{P}\left\{{ }^{1} \mathrm{H}\right\}$ NMR spectra.

Trisulfonated Biphenylphosphane Ligands

Phosphanes possessing one, two or three sulfonated biphenyl groups strongly interact with the $\beta-C D$. Indeed, complexation studies between these ligands and native $\beta$-CD showed a deep inclusion of their biphenyl moiety in the CD cavity. In all cases, stoichiometries were determined to be equal to 1:1 and association constants were particularly high (Table 1 and Supplementary Materials). Consequently, the influence of such association towards the platinum organometallic complexes was investigated.

In the case of $\mathrm{P}(\mathrm{Biph}) \mathrm{Ph}_{2} \mathrm{TS}$, modifications on the ${ }^{31} \mathrm{P}\left\{{ }^{1} \mathrm{H}\right\}$ NMR spectra are observed with RAME- $\beta$-CD addition. Complexation of the phosphane oxide by the CD is in fact detected by its chemical shift modification. Moreover, a broadening of $\left[\mathrm{PtL}_{3} \mathrm{Cl}\right] \mathrm{Cl}$ signals is observed concurrently with the lack of peak corresponding to free or CD-complexed phosphane (in the region going from 0 to $-10 \mathrm{ppm}$ ) (Figure 8). The explanation for that is the interaction between RAME- $\beta-C D$ and $\left[\mathrm{Pt}\left(\mathrm{P}(\mathrm{Biph}) \mathrm{Ph}_{2} \mathrm{TS}\right)_{3} \mathrm{Cl}\right] \mathrm{Cl}$ without inducing dissociation of the ligand from the metal centre. This theory was confirmed by the 2D T-ROESY experiment of a $1: 1 \beta-\mathrm{CD}:\left[\mathrm{Pt}\left(\mathrm{P}(\mathrm{Biph}) \mathrm{Ph}_{2} \mathrm{TS}\right)_{3} \mathrm{Cl}\right] \mathrm{Cl}[22]$ mixture which exhibited intense cross-peaks between the phosphane aromatic protons and the internal $C D$ protons $\left(\mathrm{H}_{3}\right.$ and $\left.\mathrm{H}_{5}\right)$. In that case, an organometallic complex formation where the CD plays the role of coordination second sphere ligand is highlighted (Scheme 4 ). Thus, contrary to TPPTS, three equivalents of RAME- $\beta-\mathrm{CD}$ with respect to $\mathrm{Pt}$ are not able to transform the $\left[\mathrm{PtL}_{3} \mathrm{Cl}\right] \mathrm{Cl}$ complex into $\mathrm{PtCl}_{2} \mathrm{~L}_{2}$ complex when $\mathrm{P}(\mathrm{Biph}) \mathrm{Ph}_{2} \mathrm{TS}$ is used. Nevertheless, further increase in the CD quantity (12 equivalents of RAME- $\beta-C D$ relative to $\mathrm{Pt}$ ) and temperature $\left(85^{\circ} \mathrm{C}\right)$ lead to a dissociation of the ligand from the metal centre confirmed both by the CD-included phosphane signal observed at $-3 \mathrm{ppm}$ and the formation of low-coordinated $\mathrm{PtCl}_{2} \mathrm{~L}_{2}$ species (Figure 8c).

On the other hand, when $\mathrm{P}(\mathrm{Biph})_{2} \mathrm{PhTS}$ and $\mathrm{P}(\mathrm{Biph})_{3} \mathrm{TS}$ were used, addition of large amounts of $\mathrm{CD}$ to the complexes synthetized by adding three equivalents of the previous ligands to a $\mathrm{K}_{2} \mathrm{PtCl}_{4}$ aqueous solution did not lead to a signal improvement (obtained spectra were comparable to those presented in Figure 5(a)), so in these cases, it is difficult to conclude. 


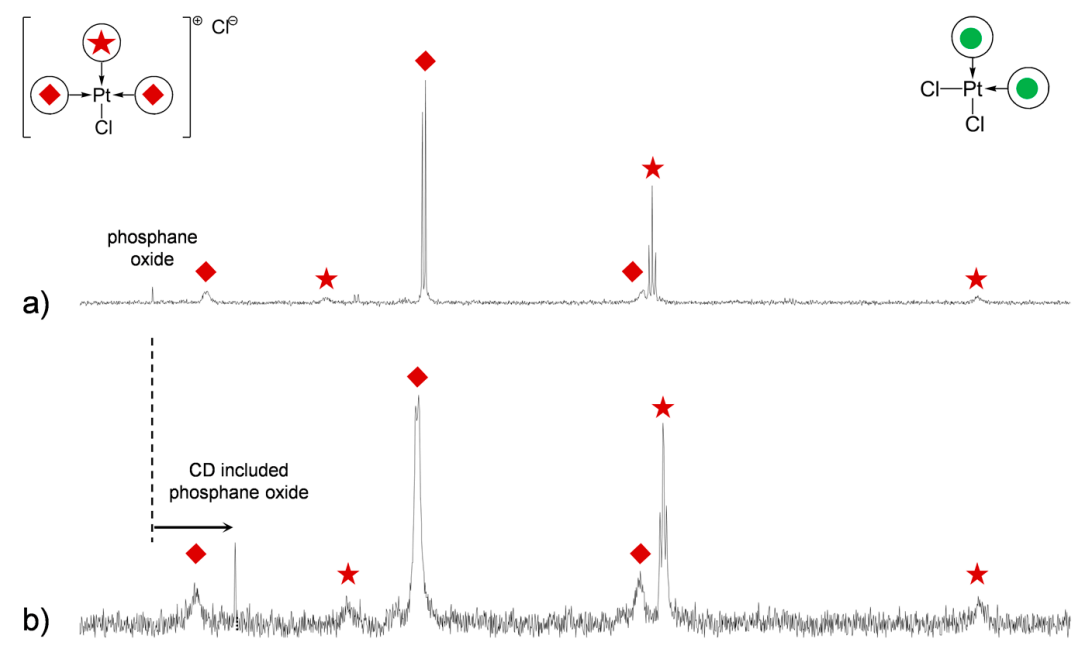

c)

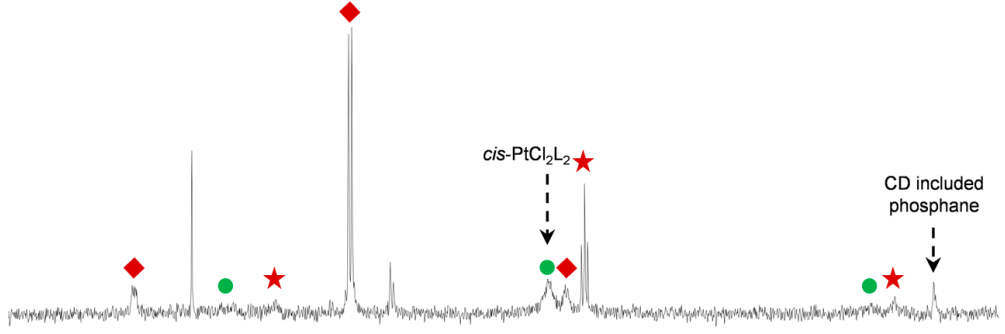
(ppm)
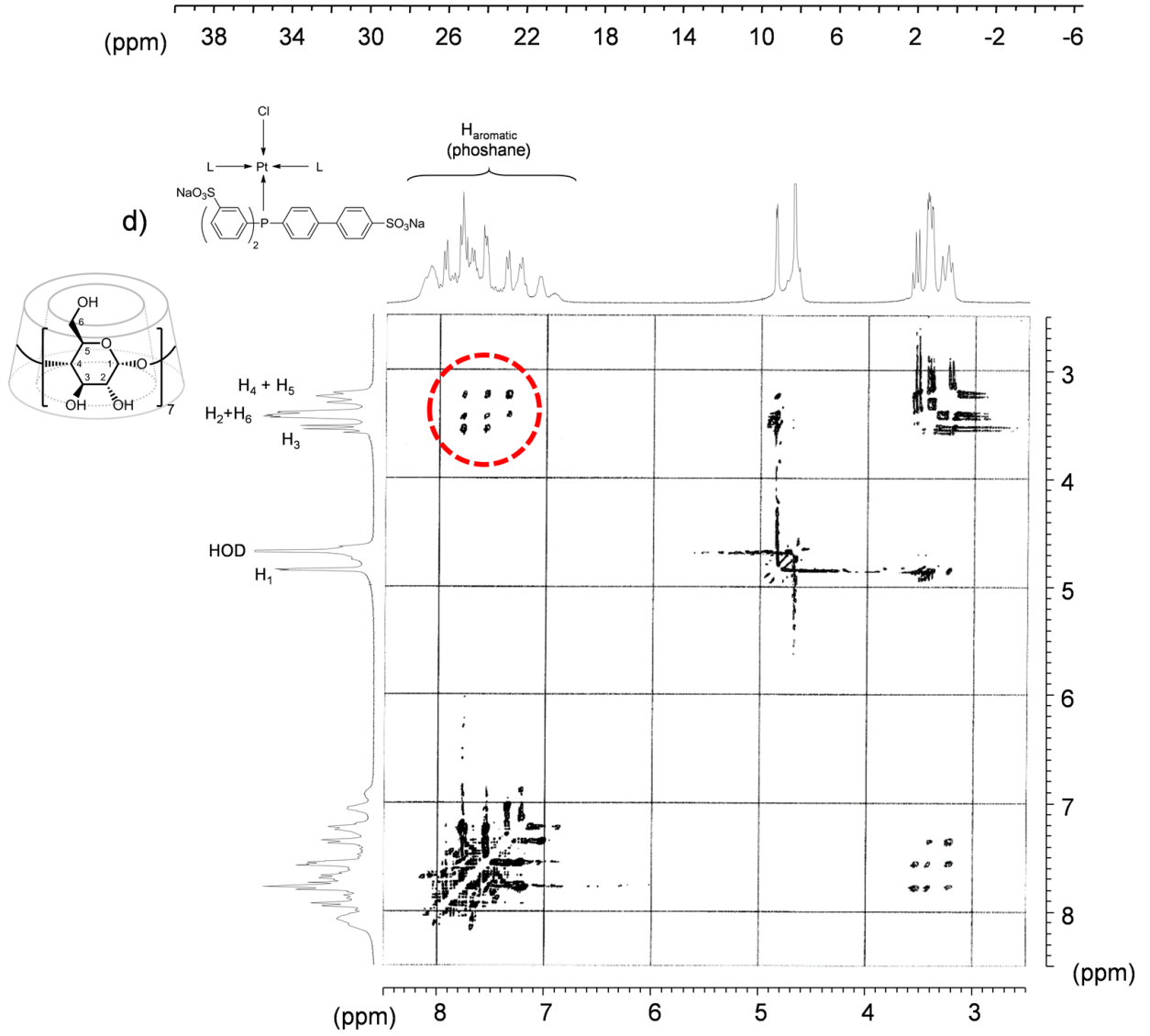

Figure 8. ${ }^{31} \mathrm{P}\left\{{ }^{1} \mathrm{H}\right\}$ NMR spectra of (a) $\left[\mathrm{Pt}\left(\mathrm{P}(\mathrm{Biph}) \mathrm{Ph}_{2} \mathrm{TS}\right)_{3} \mathrm{Cl}\right] \mathrm{Cl} 10 \mathrm{mM}$; (b) +3 equiv. of RAME- $\beta-\mathrm{CD}$ toward $\mathrm{Pt}$ at $25^{\circ} \mathrm{C}$ (c) +12 equiv. of RAME- $\beta$-CD toward $\mathrm{Pt}$ at $85^{\circ} \mathrm{C}$ (d) $2 \mathrm{D}$ T-ROESY spectrum of a solution containing $\beta-\mathrm{CD}(10 \mathrm{mM})$ and $\left[\mathrm{Pt}\left(\mathrm{P}(\mathrm{Biph}) \mathrm{Ph}_{2} \mathrm{TS}\right){ }_{3} \mathrm{Cl}\right] \mathrm{Cl}(10 \mathrm{mM})$ at $25^{\circ} \mathrm{C}$ in $\mathrm{D}_{2} \mathrm{O}$. 


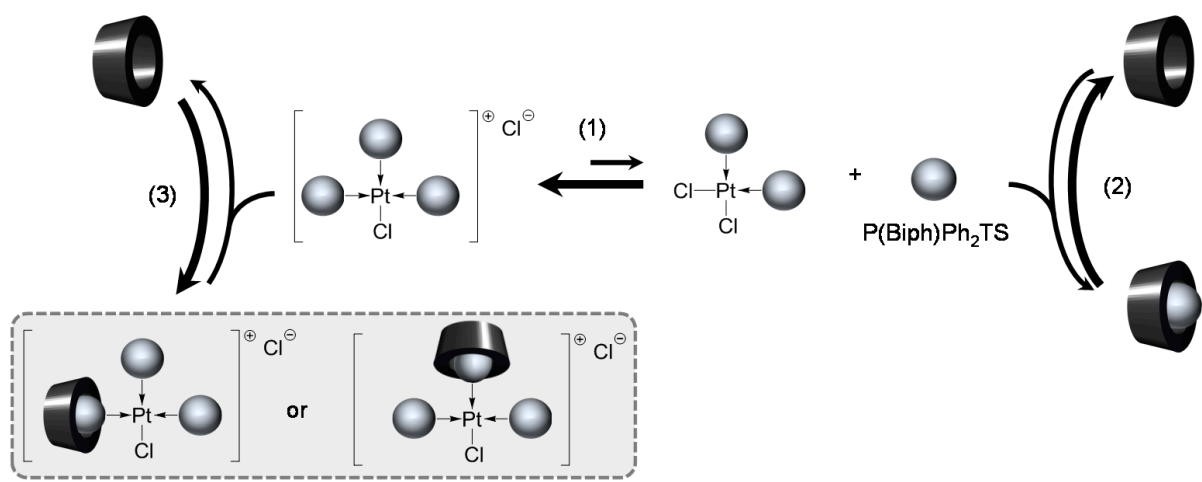

Scheme 4. Equilibria between the different platinum species with $\mathrm{P}(\mathrm{Biph}) \mathrm{Ph}_{2} \mathrm{TS}$ as ligand in the presence of 3 equiv. of RAME- $\beta$-CD toward $\mathrm{Pt}$ (species observed on the ${ }^{31} \mathrm{P}\left\{{ }^{1} \mathrm{H}\right\}$ NMR spectrum are presented on a grey background).

A short overview of this platinum study is presented in Table 2. To sum up, low-coordinated catalytic species $\mathrm{PtCl}_{2} \mathrm{~L}_{2}$ are formed when ortho-substituted TPPTS derivatives are used or when TPPTS-based complexes are combined with RAME- $\beta-C D$ (trans and cis geometry respectively). In the first case, these species are obviously formed due to the larger cone angles of these ortho-substituted ligands. In the second case, the relative $\sigma$-donating power of the TPPTS ligand, through the presence of the attractive meta sodium sulfonato groups, makes the ligand-metal bond weak and hence RAME- $\beta-C D$ is able to shift the equilibria between the different organometallic species towards the formation of low-coordinated species by the formation of inclusion complex with the ligand. However, although the association constant between tris( $p$-Me)TPPTS and RAME- $\beta$-CD is higher than the one between TPPTS and RAME- $\beta-C D$, low-coordinated platinum complexes are not observed.

Table 2. Organometallic species formed by adding 3 equiv. of ligand to a $\mathrm{K}_{2} \mathrm{PtCl}_{4}$ aqueous solution (10 $\mathrm{mM})$ and after RAME- $\beta$-CD addition ( 1 to 12 equiv. toward platinum).

\begin{tabular}{|c|c|c|c|}
\hline Ligand & $\begin{array}{l}\text { Platinum Complex } \\
\text { Obtained without CD }\end{array}$ & $\begin{array}{l}\text { New Species Obtained } \\
\text { after RAME- } \beta \text {-CD Addition }\end{array}$ & \\
\hline TPPTS & $\begin{array}{c}{\left[\mathrm{PtL}_{3} \mathrm{Cl}\right] \mathrm{Cl}=} \\
\overbrace{}^{\oplus}]^{\oplus \mathrm{Cl}^{\ominus}}\end{array}$ & cis- $\mathrm{PtCl}_{2} \mathrm{~L}_{2}=$ & \\
\hline $\operatorname{tris}(p-\mathrm{Me}) \mathrm{TPPTS}$ & {$\left[\mathrm{PtL}_{3} \mathrm{Cl}\right] \mathrm{Cl}$} & - & \\
\hline $\operatorname{tris}(p$-OMe)TPPTS & {$\left[\mathrm{PtL}_{3} \mathrm{Cl}\right] \mathrm{Cl}$} & - & \\
\hline $\operatorname{tris}(o-\mathrm{Me}) \mathrm{TPPTS}$ & $\begin{array}{c}\text { trans }-\mathrm{PtCl}_{2} \mathrm{~L}_{2}= \\
\mathrm{Cl}_{\mathrm{I}} \\
\rightarrow \rightarrow \mathrm{Pt}\end{array}$ & - & \\
\hline tris $(o-\mathrm{OMe}) \mathrm{TPPTS}$ & trans $-\mathrm{PtCl}_{2} \mathrm{~L}_{2}$ & - & \\
\hline $\mathrm{P}(\mathrm{Biph}) \mathrm{Ph}_{2} \mathrm{TS}$ & {$\left[\mathrm{PtL}_{3} \mathrm{Cl}\right] \mathrm{Cl}$} & & \\
\hline $\mathrm{P}(\mathrm{Biph})_{2} \mathrm{PhTS}$ & n.d (broad signals) * & n.d (broad signals) & \\
\hline $\mathrm{P}(\mathrm{Biph})_{3} \mathrm{TS}$ & n.d (broad signals) * & n.d (broad signals) & \\
\hline
\end{tabular}

This behaviour comes from the highest $\sigma$-donating power of this ligand compared to TPPTS through the presence of the donating para methyl groups which makes the ligand-metal bond stronger. 
Furthermore, given that tris $(p-\mathrm{OMe}) \mathrm{TPPTS}$ does not interact with RAME- $\beta-\mathrm{CD}$, its coordination behaviour towards platinum(II) is not affected by the CD addition. Finally, formation of organometallic species where the RAME- $\beta$-CD plays the role of coordination second sphere ligand is observed when $\mathrm{P}(\mathrm{Biph}) \mathrm{Ph}_{2} \mathrm{TS}$, which possesses a CD-recognised moiety, is used in combination with one equivalent of RAME- $\beta-C D$ towards the ligand. It is important to emphasize that further increase in the CD quantity yields to the formation of low-coordinated species. The formation of organometallic species possessing more than one $\mathrm{CD}$ in their coordination second sphere would probably yield to a steric decompression trough the decoordination of the $\mathrm{CD}$ included phosphane.

\subsection{Palladium Complexes}

The RAME- $\beta$-CD influence on organometallic species was extended to palladium (0) complexes. The palladium extraction from a toluene solution of $\mathrm{Pd}(\mathrm{TPP})_{4}$ to an aqueous phase by the hydrosoluble ligand yields to isolation of $\mathrm{PdL}_{x}$ complexes (see "materials and methods" part). In the case of TPPTS, this study has already been published by our group [19]. It was concluded that the addition of RAME- $\beta$-CD only yields to a chemical exchange rate decrease between free TPPTS and the Pd(TPPTS $)_{3}$ complex caused by the formation of the inclusion complex RAME- $\beta$-CD/TPPTS. Furthermore, no new palladium species were observed, even at high temperature $\left(60^{\circ} \mathrm{C}\right)$.

\subsubsection{Para-Substituted TPPTS Derivatives}

\section{$[\operatorname{Pd}(0) / \operatorname{tris}(p-\mathrm{Me}) \mathrm{TPPTS}]$ Complex}

${ }^{31} \mathrm{P}\left\{{ }^{1} \mathrm{H}\right\}$ NMR spectra of $\mathrm{Pd}(\operatorname{tris}(p-\mathrm{Me}) \mathrm{TPPTS})_{3}$ complexes in addition to different RAME- $\beta-\mathrm{CD}$ concentrations and at different temperatures are given in Figure 9. Without $C D$, two different resonances are observed. Besides the minor phosphane oxide signal at $34 \mathrm{ppm}$, a broad signal was detected at $19.5 \mathrm{ppm}$ which corresponds to the average signal of the $\operatorname{Pd}(\operatorname{tris}(p-\mathrm{Me}) \mathrm{TPPTS})_{3}$ complex in fast equilibrium with a small amount of free residual tris( $p$-Me)TPPTS ligand $[19,23]$. Higher temperatures have no effects on this equilibrium. Adding three equivalents of RAME- $\beta-C D$ yields to an exchange rate decrease between the $\operatorname{Pd}(\operatorname{tris}(p-\mathrm{Me}) \mathrm{TPPTS})_{3}$ species, which signal becomes sharp at $21.8 \mathrm{ppm}$, and the small excess of free ligand by its encapsulation in the CD cavity ( $-11.2 \mathrm{ppm})$. Higher $\mathrm{CD}$ concentrations combined with higher temperatures do not lead to the formation of new palladium species. Hence, like what was observed with the platinum(II) complexes, addition of RAME- $\beta$-CD does not change the nature of the organometallic complex, albeit association constant between the $C D$ and the ligand is greater than that of the RAME- $\beta-C D / T P P T S$ inclusion complex.

\section{$[\mathrm{Pd}(0) / \operatorname{tris}(p$-OMe)TPPTS] Complex}

Addition of large amount of RAME- $\beta$-CD (12 equiv. with respect to $\mathrm{Pd}$ ) to the $\mathrm{Pd}$ (tris $(p \text {-OMe)TPPTS })_{3}$ complex does not modify the ${ }^{31} \mathrm{P}\left\{{ }^{1} \mathrm{H}\right\}$ NMR spectrum as this ligand does not interact with the CD. In fact, even at high temperature, a broad signal at $19 \mathrm{ppm}$ is detected which corresponds to the average signal of the equilibrium between the organometallic complex and free tris(p-OMe)TPPTS (Figure 10).

\subsection{2. ortho-Substituted Ligands}

The same experiments were realized with the ortho-substituted ligands but the synthesis of the $\mathrm{PdL}_{3}$ complex failed. Indeed, Pd extraction from the organic phase to the aqueous phase is too low. The bulkiness of the hydrosoluble ortho-substituted are obviously responsible for the equilibrium displacement toward the organic $\mathrm{Pd}(\mathrm{TPP})_{4}$ complex. Again, these results are in accordance with the previous observations made with the platinum complexes study showing that these ligands hardly coordinate the metal centre. 


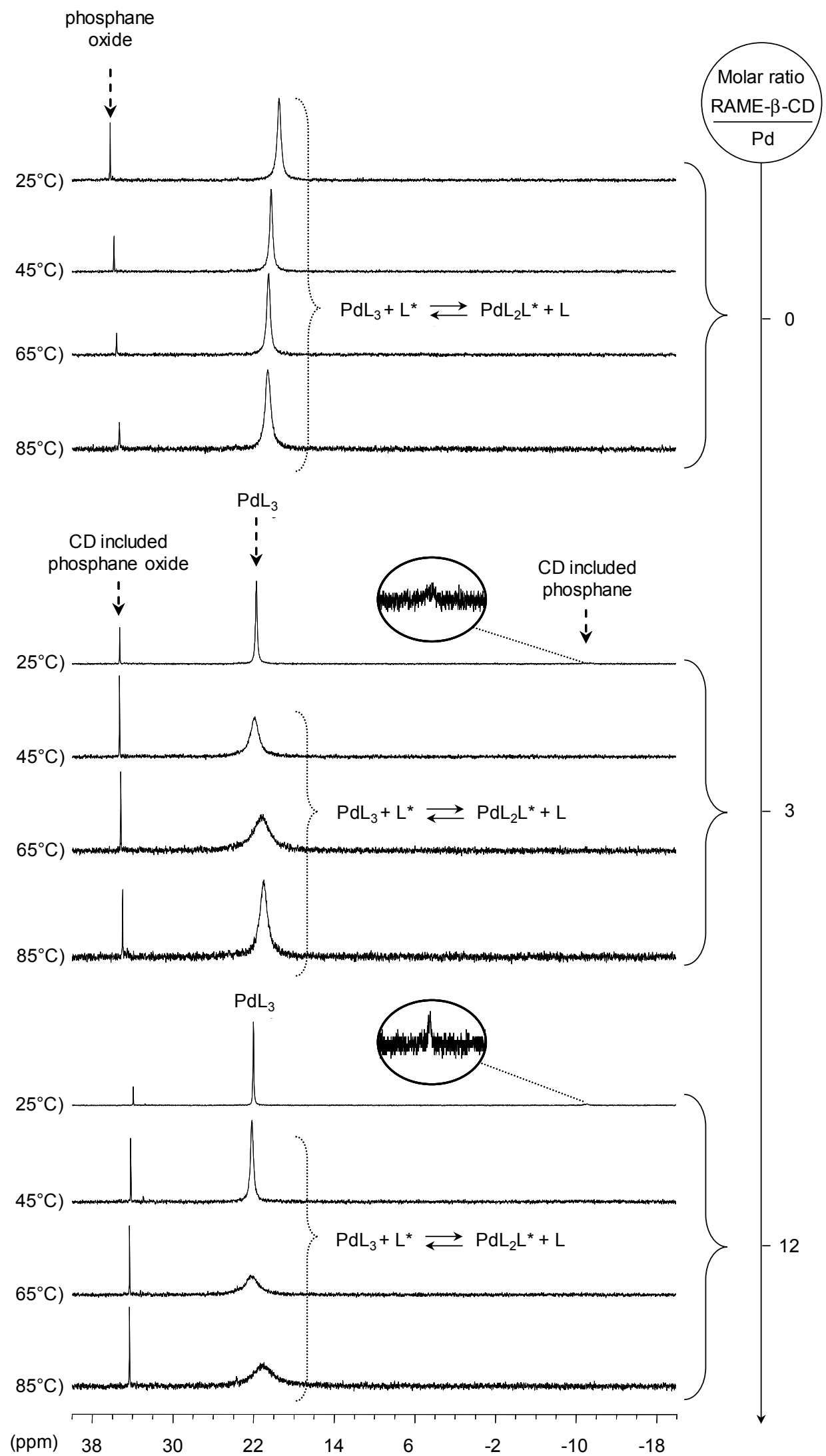

Figure 9. ${ }^{31} \mathrm{P}\left\{{ }^{1} \mathrm{H}\right\}$ NMR spectra of $\operatorname{Pd}(\operatorname{tris}(p-\mathrm{Me}) \mathrm{TPPTS})_{3}$ depending on both temperature and RAME- $\beta$-CD quantity in $\mathrm{D}_{2} \mathrm{O}$ with a ligand concentration of $66 \mathrm{mM}$. 


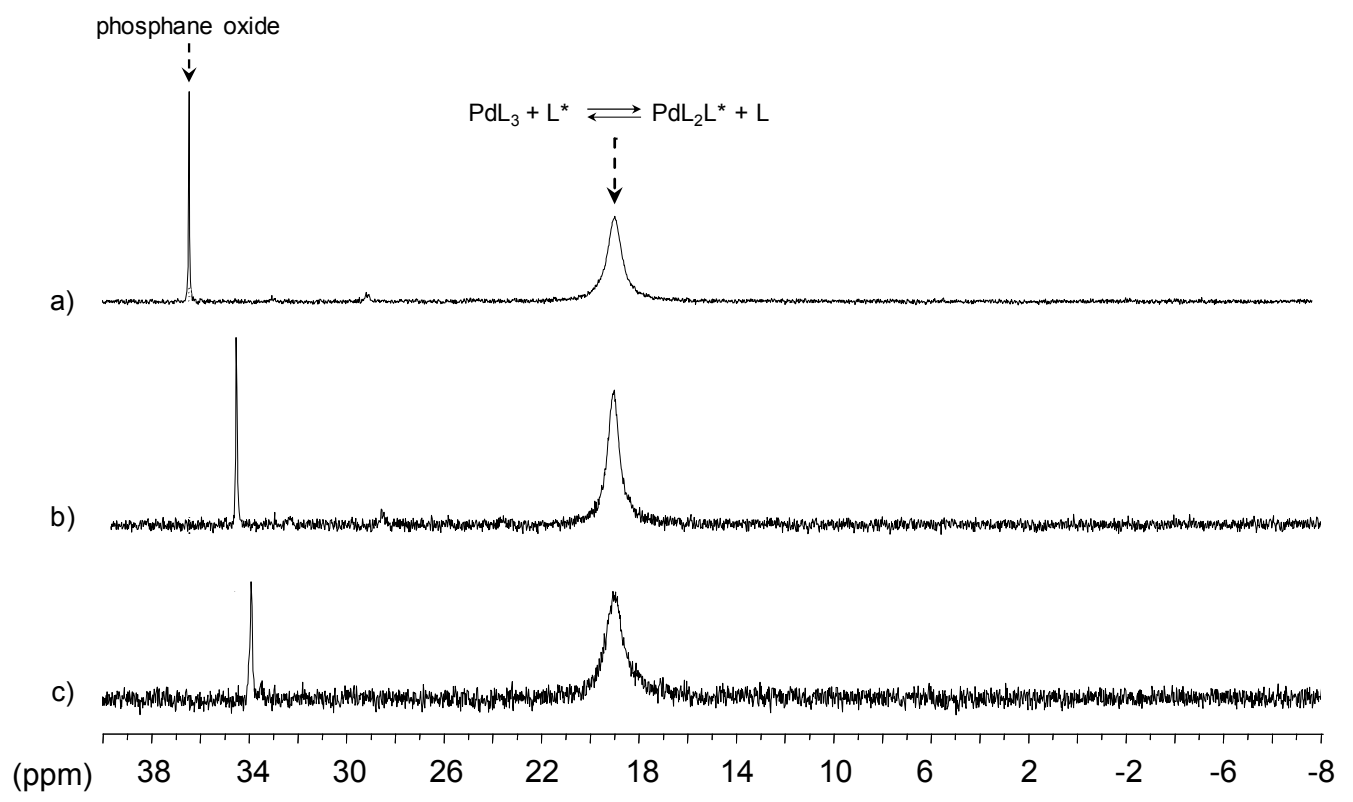

Figure 10. ${ }^{31} \mathrm{P}\left\{{ }^{1} \mathrm{H}\right\} \mathrm{NMR}$ spectra of $\mathrm{Pd}(\operatorname{tris}(p-\mathrm{OMe}) \mathrm{TPPTS})_{3}$ at $(\mathbf{a}) 25^{\circ} \mathrm{C} ;(\mathbf{b})+12$ equiv. of RAME- $\beta$-CD at $25^{\circ} \mathrm{C}(\mathbf{c})+12$ equiv. of RAME- $\beta-\mathrm{CD}$ at $85^{\circ} \mathrm{C}$ in $\mathrm{D}_{2} \mathrm{O}$ with a ligand concentration of $66 \mathrm{mM}$.

\subsubsection{Biphenylphosphane Ligands}

\section{$\left[\mathrm{Pd}(0) / \mathrm{P}(\mathrm{Biph}) \mathrm{Ph}_{2} \mathrm{TS}\right]$ Complex}

In this case, comments are identical to the previous $\operatorname{Pd}(\operatorname{tris}(p-\mathrm{Me}) \mathrm{TPPTS})_{3}$ complex (see ESI). That is to say, $\mathrm{CD}$ addition to a $\mathrm{Pd}\left(\mathrm{P}(\mathrm{Biph}) \mathrm{Ph}_{2} \mathrm{TS}\right)_{3}$ aqueous solution reduces the chemical exchange rate between free ligand and the organometallic complex. Increasing both temperature and RAME- $\beta-C D$ quantity do not yield to the formation of other palladium species. However, 2D NMR T-ROESY experiment of a 1:1 $\beta-\mathrm{CD}: \mathrm{Pd}\left(\mathrm{P}(\mathrm{Biph}) \mathrm{Ph}_{2} \mathrm{TS}\right)_{3}$ mixture exhibited intense cross-peaks between the phosphane aromatic protons and the internal $\mathrm{CD}$ protons $\mathrm{H}_{3}$ and $\mathrm{H}_{5}$ (Figure 11). The presence of only $4 \%$ (determined by integration of the ${ }^{31} \mathrm{P}\left\{{ }^{1} \mathrm{H}\right\}$ NMR spectrum) of free ligand which is trapped by the $\mathrm{CD}$ in the mixture could not be responsible for such intense cross peaks. Therefore, absence of new palladium species together with strong correlation between the CD and the ligand in the 2D T-ROESY NMR spectrum enable us to assume the formation of inclusion complex between the CD and the ligand (coordinated to the palladium centre). As with the platinum complex, the $\mathrm{P}(\mathrm{Biph}) \mathrm{Ph}_{2} \mathrm{TS}$ ligand allows the formation of organometallic palladium species where the cyclodextrin plays the role of coordination second sphere ligand.

Furthermore, intense cross-peaks between the $\mathrm{CD}$ internal $\mathrm{H}_{3}$ protons and $\mathrm{H}_{\mathrm{a}}$ of the biphenyl moiety together with high correlations between the $C D$ internal $\mathrm{H}_{5}$ protons and $\mathrm{H}_{\mathrm{c}} / \mathrm{H}_{\mathrm{d}}$ of the biphenyl moiety in the T-ROESY spectrum allow us to propose a geometry where the phosphane penetration in the CD cavity takes place via the primary face (Scheme 5).

It should be noted however, that this geometry differs from the geometry of the inclusion complex between the free ligand in solution and the $C D$ which takes place via the CD secondary face (see ESI). The spatial proximity of the palladium coordinated ligands inevitably leads to a high steric hindrance which could be responsible for such a difference in the geometry. 


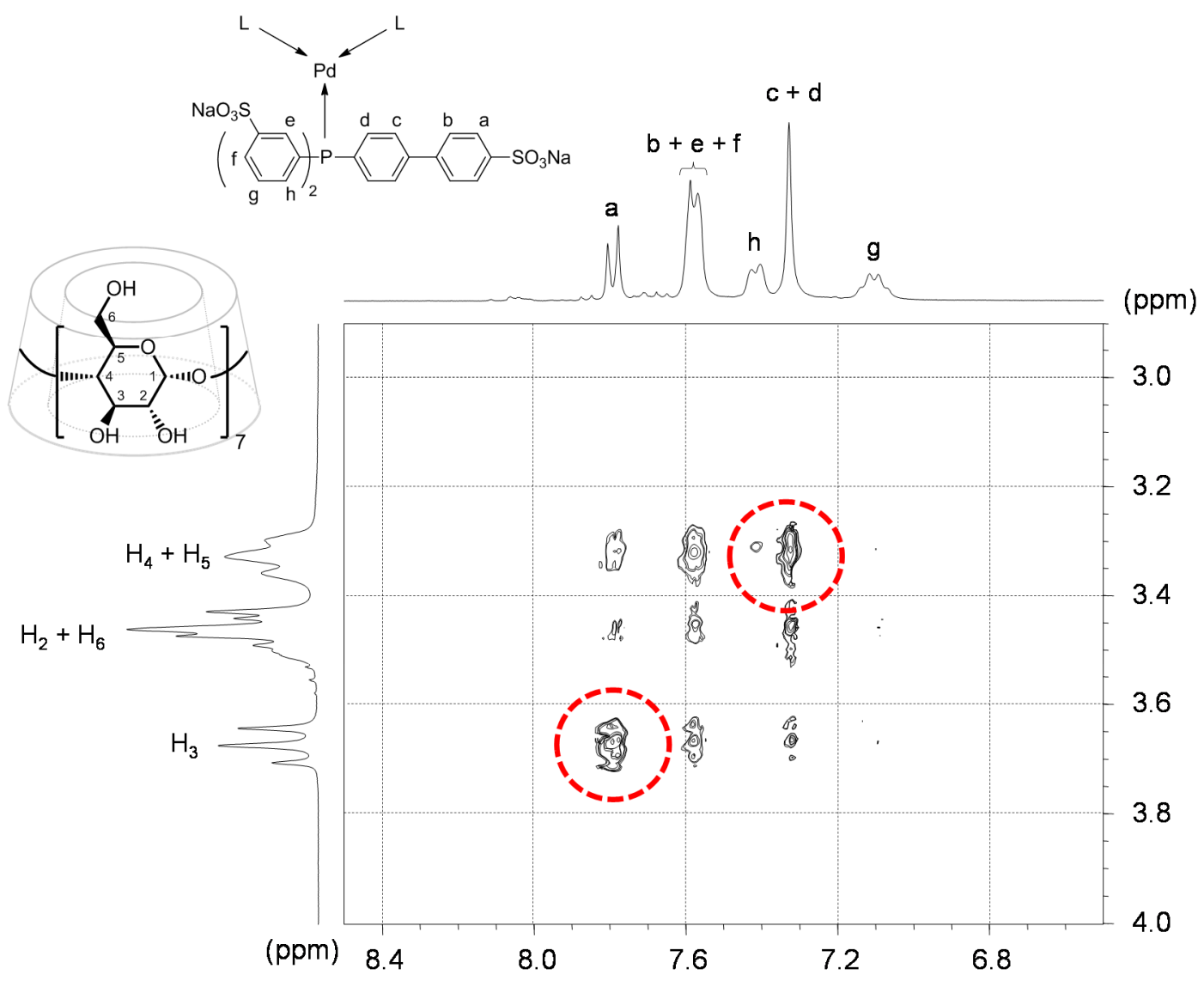

Figure 11. 2D T-ROESY spectrum of a solution containing $\beta-\mathrm{CD}(11 \mathrm{mM})$ and $\mathrm{Pd}\left(\mathrm{P}(\mathrm{Biph}) \mathrm{Ph}_{2} \mathrm{TS}\right)_{3}$ $(11 \mathrm{mM})$ at $25^{\circ} \mathrm{C}$ in $\mathrm{D}_{2} \mathrm{O}$.

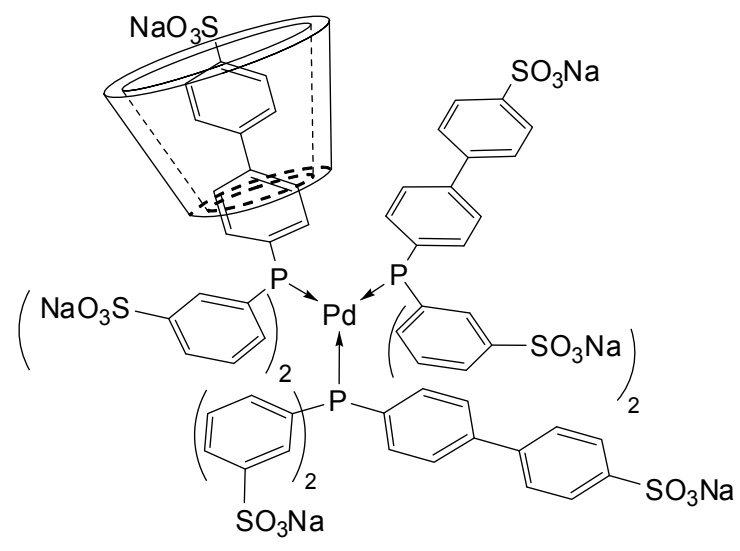

Scheme 5. Possible geometry of the organometallic palladium species where CD plays the role of coordination second sphere ligand.

$\left[\mathrm{Pd}(0) / \mathrm{P}(\text { Biph })_{2} \mathrm{PhTS}\right]$ Complex

${ }^{31} \mathrm{P}\left\{{ }^{1} \mathrm{H}\right\}$ NMR spectra of $\mathrm{Pd}\left(\mathrm{P}(\mathrm{Biph})_{2} \mathrm{PhTS}\right)_{3}$ complexes in addition to different RAME- $\beta-\mathrm{CD}$ concentrations and at different temperatures are given in Figure 12. 


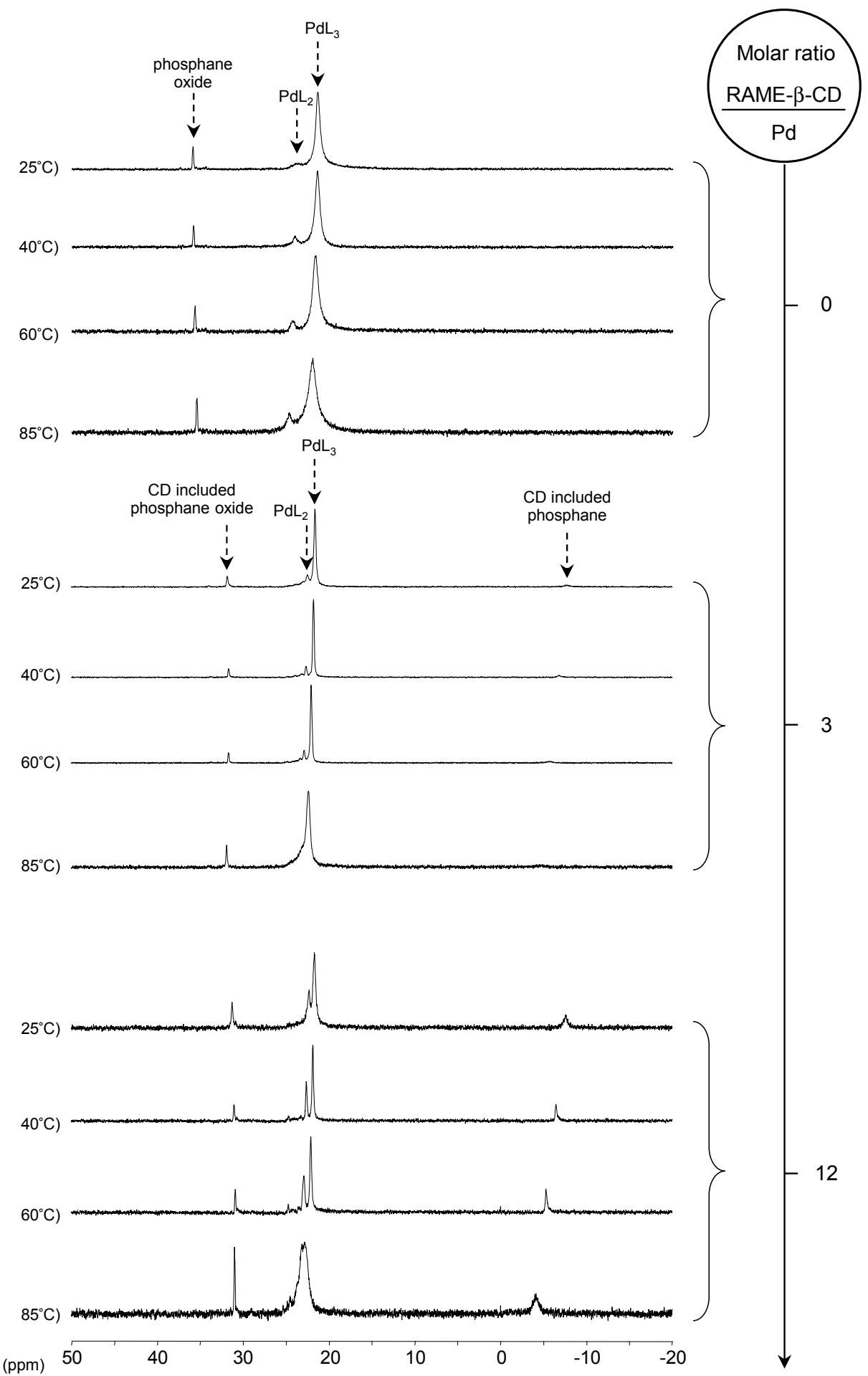

Figure 12. ${ }^{31} \mathrm{P}\left\{{ }^{1} \mathrm{H}\right\}$ NMR spectra of palladium complexes synthetized with $\mathrm{P}(\mathrm{Biph}){ }_{2} \mathrm{PhTS}$ depending on both temperature and RAME- $\beta-C D$ quantity in $\mathrm{D}_{2} \mathrm{O}$ with a ligand concentration of $66 \mathrm{mM}$.

At room temperature and without $\mathrm{CD}$, two different broad signals corresponding to the $\mathrm{PdL}_{3}$ and $\mathrm{PdL}_{2}$ complexes in fast equilibrium with free ligand are observed. Neither temperature, nor addition of 3 equiv. of RAME- $\beta$-CD do not allow to observe new organometallic species. Indeed, CD addition only leads to the apparition of the complexed free ligand at $-7.5 \mathrm{ppm}$, a phosphane oxide chemical shift trapped by the CD and a sharpening of the organometallic complexes signals which are in equilibrium. However, addition of 12 equiv. of RAME- $\beta-C D$ leads to a diminution of the $\mathrm{PdL}_{3}$ species in favour 
of the $\mathrm{PdL}_{2}$ species and free ligand trapped by the $\mathrm{CD}$. On the other hand, temperature increase has a negligible influence on the $\mathrm{PdL}_{3} / \mathrm{PdL}_{2}$ ratio. At high temperature, natural dissociation increase of the $\mathrm{PdL}_{3}$ species is probably offset by the stability diminution of the inclusion complex between the $\mathrm{CD}$ and the phosphane. To sum up, high $\mathrm{CD}$ quantity is able to shift the equilibrium between the different palladium species towards the formation of low-coordinated species (Scheme 6).

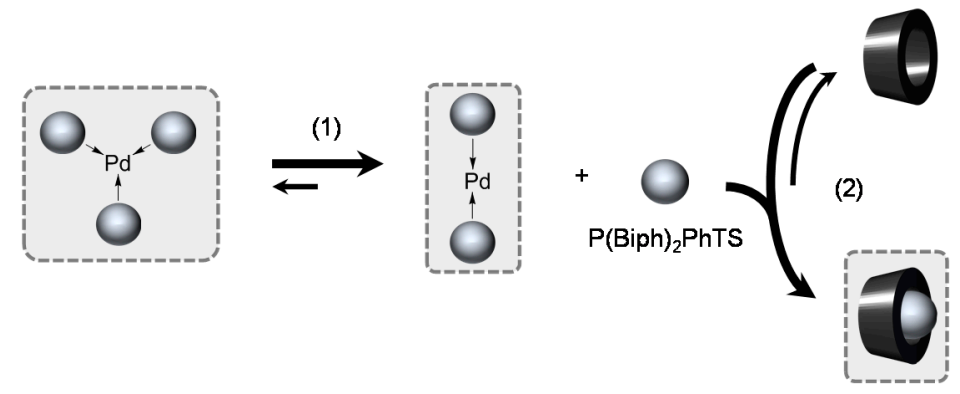

Scheme 6. Equilibria between the different palladium species with $\mathrm{P}(\mathrm{Biph})_{2} \mathrm{PhTS}$ as ligand in the presence of 12 equiv. of RAME- $\beta$-CD toward palladium (species observed on the ${ }^{31} \mathrm{P}\left\{{ }^{1} \mathrm{H}\right\} \mathrm{NMR}$ spectrum are presented on a grey background).

\section{$\left[\operatorname{Pd}(0) / \mathrm{P}(\mathrm{Biph})_{3} \mathrm{TS}\right]$ Complex}

As already described [16], the ligand $\mathrm{P}(\mathrm{Biph})_{3} \mathrm{TS}$ forms a new palladium species at room temperature:PdL 4 which have a chemical shift of $15 \mathrm{ppm}$. Without $\mathrm{CD}, \mathrm{PdL}_{3}$ and $\mathrm{PdL}_{4}$ species are in slow equilibrium. Indeed, when the temperature is increased, the signals of both complexes are broadened and merge together at $85^{\circ} \mathrm{C}$ (Figure 13). Moreover, the NMR spectrum carried out at room temperature after heating gave the same signals reflecting the reversibility of the process.

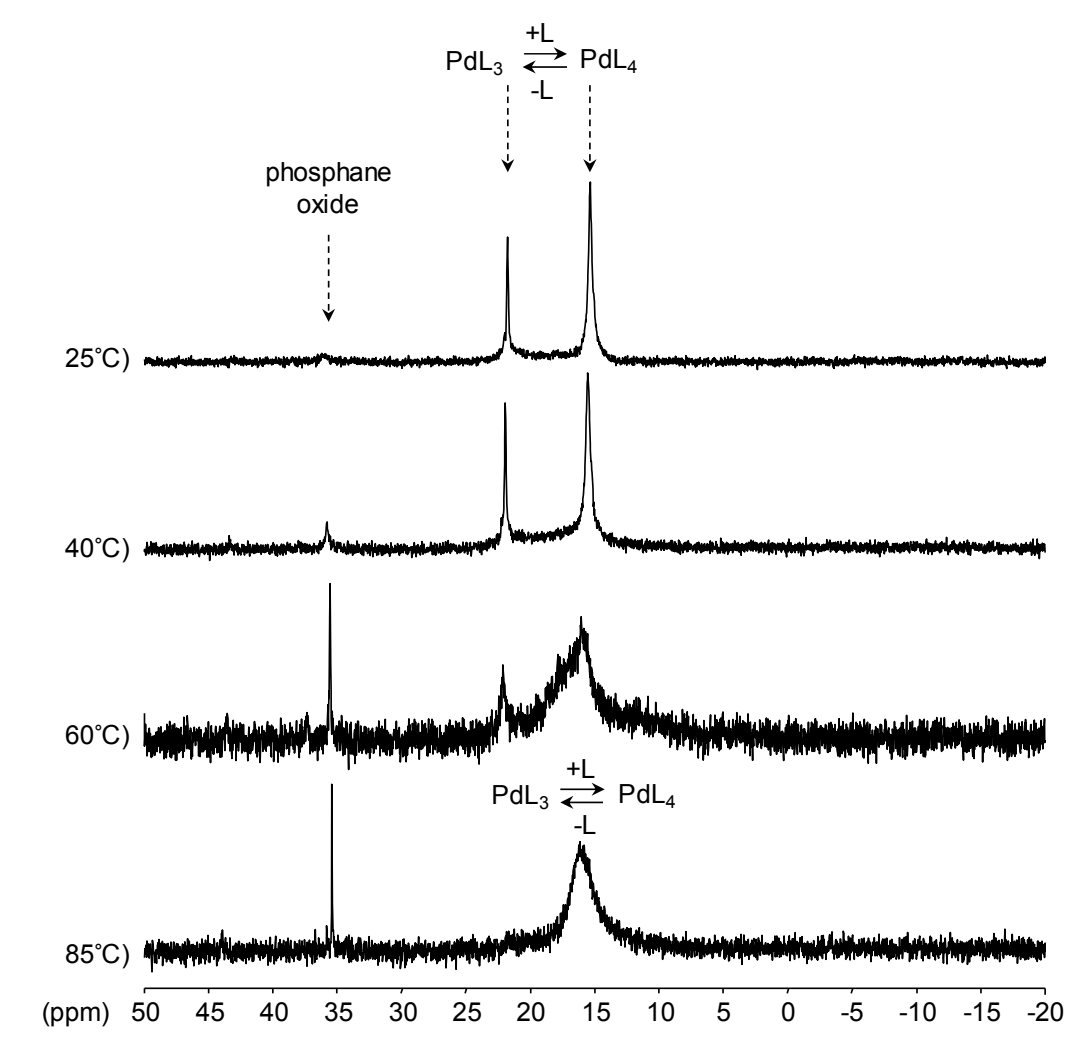

Figure 13. ${ }^{31} \mathrm{P}\left\{{ }^{1} \mathrm{H}\right\}$ NMR spectra of palladium complexes synthetized with $\mathrm{P}(\mathrm{Biph})_{3} \mathrm{TS}$ depending on temperature in $\mathrm{D}_{2} \mathrm{O}$ with a ligand concentration of $66 \mathrm{mM}$. 
By adding increasing amounts of RAME- $\beta-C D$, the $\mathrm{PdL}_{4}$ signal disappears concurrently with an increase of both the $\mathrm{PdL}_{3}$ signal and the free ligand trapped by the $\mathrm{CD}$ (Figure 14).

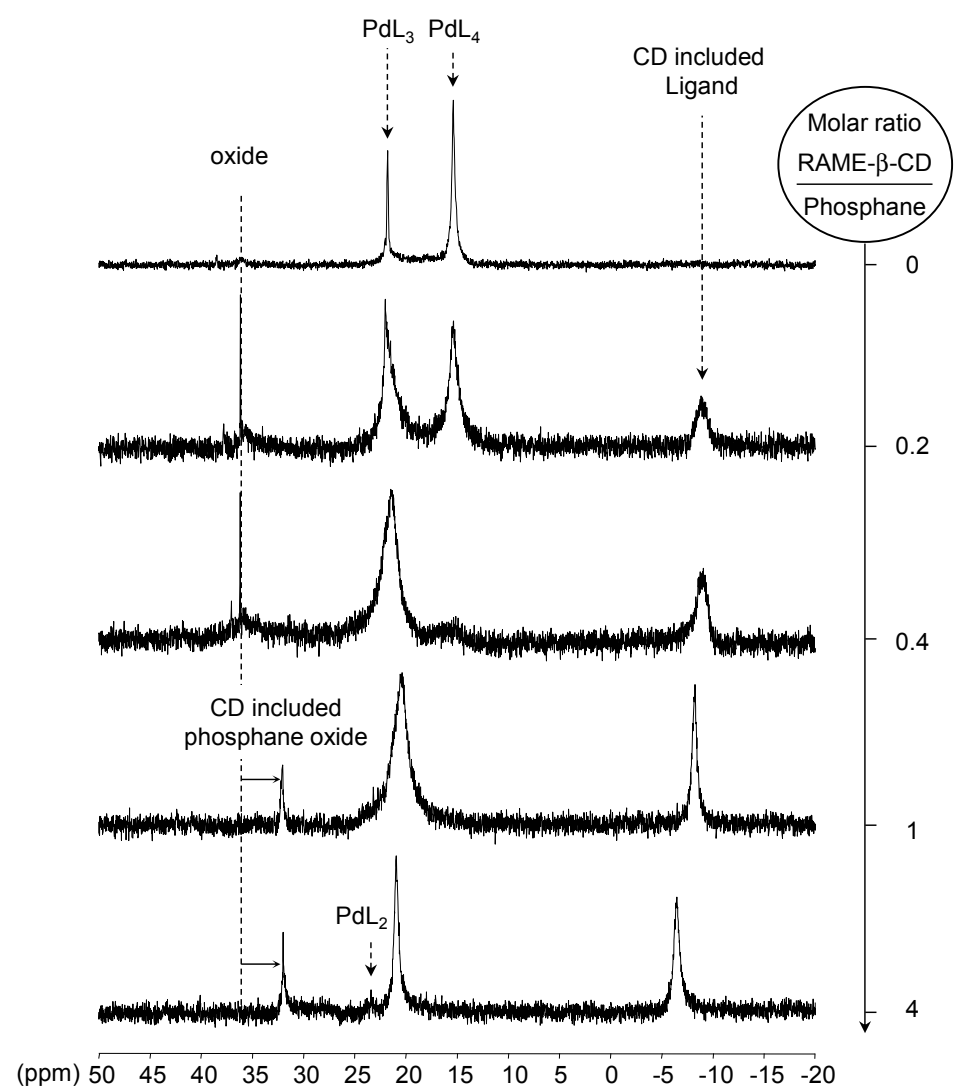

Figure 14. ${ }^{31} \mathrm{P}\left\{{ }^{1} \mathrm{H}\right\}$ NMR spectra effect of RAME- $\beta-C D$ quantity on the equilibrium of the different palladium species formed with the ligand $\mathrm{P}(\mathrm{Biph})_{3} \mathrm{TS}$ in $\mathrm{D}_{2} \mathrm{O}$ at $25^{\circ} \mathrm{C}$ with a ligand concentration of $66 \mathrm{mM}$.

When the $C D$ quantity reaches four equivalents of ligand, species $\mathrm{PdL}_{2}$ appears. Similarly to the above-mentioned $\mathrm{Pd}\left(\mathrm{P}(\mathrm{Biph})_{2} \mathrm{PhTS}\right)_{3}$ complex, temperature has a negligible influence on the $\mathrm{PdL}_{3} / \mathrm{PdL}_{2}$ ratio when $\mathrm{P}(\mathrm{Biph})_{3} \mathrm{TS}$ is used (Figure 15). Again, RAME- $\beta-\mathrm{CD}$ is able to shift the equilibria between the different palladium organometallic species when $\mathrm{P}(\mathrm{Biph})_{3} \mathrm{TS}$ is used as ligand.

A short overview of this palladium study is presented in Table 3. To sum up, the different ligands used in this study can be classified in three categories:

(1) ligands forming palladium complexes not affected by the RAME- $\beta$-CD addition (TPPTS, tris( $p$-Me)TPPTS and tris( $p$-OMe)TPPTS)

(2) ligands forming palladium complexes where the $\mathrm{CD}$ could play the role of coordination second sphere ligand $\left(\mathrm{P}(\mathrm{Biph}) \mathrm{Ph}_{2} \mathrm{TS}\right)$

(3) ligands forming palladium complexes which are transformed by the presence of RAME- $\beta-C D$. Indeed, $\mathrm{P}(\mathrm{Biph})_{2} \mathrm{PhTS}$ and $\mathrm{P}(\mathrm{Biph})_{3} \mathrm{TS}$ spontaneously form respectively $\mathrm{PdL}_{3} / \mathrm{PdL}_{2}$ and $\mathrm{PdL}_{4} / \mathrm{PdL}_{3}$ organometallic complexes which are converted in $\mathrm{PdL}_{2}$ complexes when $\mathrm{CD}$ is added due to shift equilibria between the different organometallic species. However, formation of species where the $\mathrm{CD}$ acts as coordination second sphere ligand could not be avoided as the biphenyl moiety is well recognised by its cavity. In these cases, the organometallic complexes formed would naturally evolve to low-coordinated species through steric decompression by ligand decoordination. 


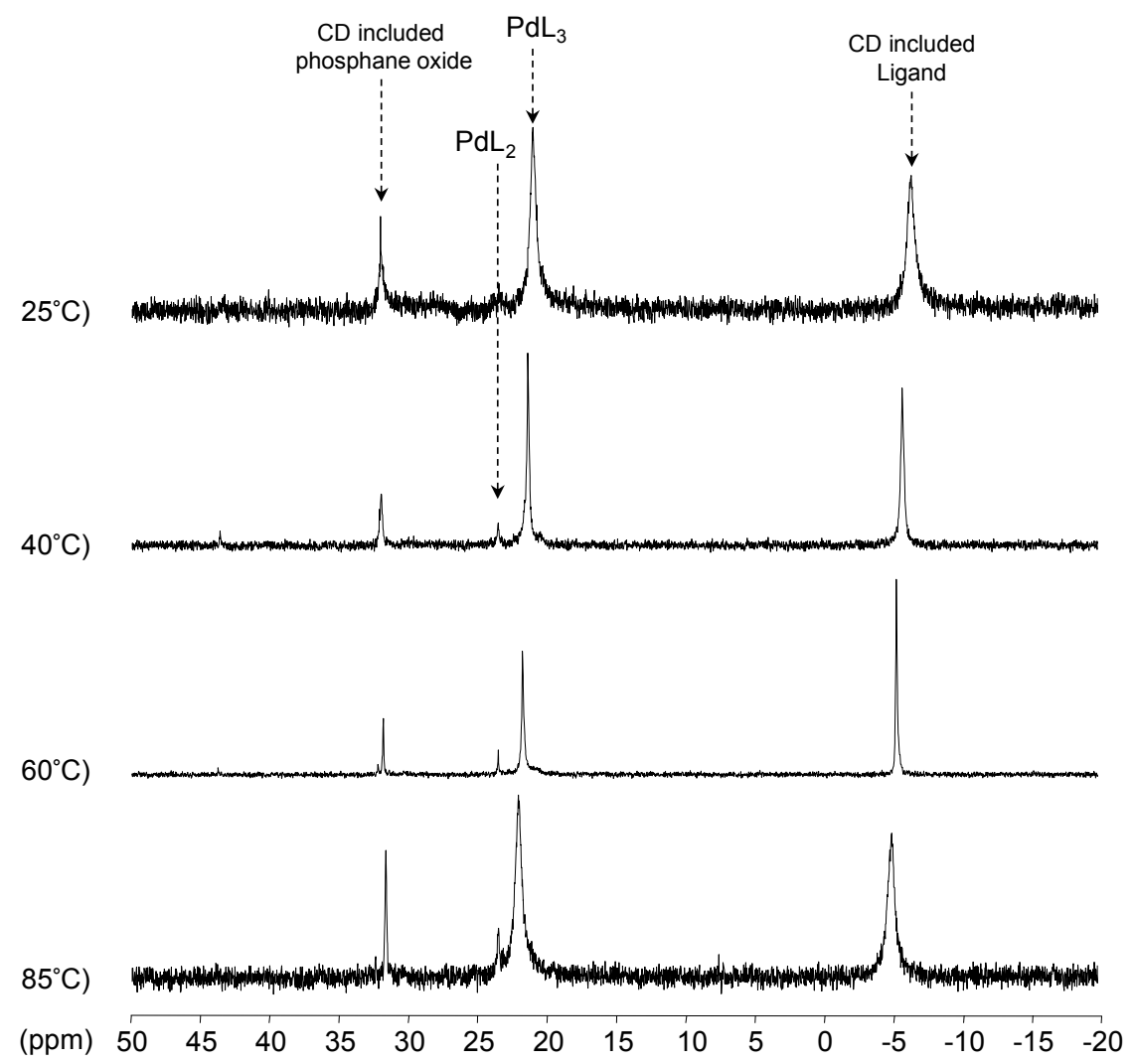

Figure 15. ${ }^{31} \mathrm{P}\left\{{ }^{1} \mathrm{H}\right\}$ NMR spectra of palladium complexes synthetized with $\mathrm{P}(\mathrm{Biph})_{3} \mathrm{TS}$ depending on temperature in the presence of 4 equiv. of RAME- $\beta-C D$ towards the phosphane in $\mathrm{D}_{2} \mathrm{O}$ with a ligand concentration of $66 \mathrm{mM}$.

Table 3. New organometallic species observed after RAME- $\beta$-CD addition (1 to 12 equiv. toward palladium) to a solution of the palladium complexes formed by extraction with an aqueous ligand solution $(66 \mathrm{mM})$.

\begin{tabular}{|c|c|c|}
\hline Ligand & $\begin{array}{l}\text { Palladium Complex } \\
\text { Obtained without CD }\end{array}$ & $\begin{array}{l}\text { New Species Obtained } \\
\text { after RAME- } \beta-C D \text { Addition }\end{array}$ \\
\hline TPPTS & $\mathrm{PdL}_{3}$ & - \\
\hline tris $(p-\mathrm{Me}) \mathrm{TPPTS}$ & $\mathrm{PdL}_{3}$ & - \\
\hline $\operatorname{tris}(p-\mathrm{OMe}) \mathrm{TPPTS}$ & $\mathrm{PdL}_{3}$ & - \\
\hline $\operatorname{tris}(o-\mathrm{Me}) \mathrm{TPPTS}$ & No palladium extraction & - \\
\hline tris $(o-\mathrm{OMe}) \mathrm{TPPTS}$ & No palladium extraction & - \\
\hline $\mathrm{P}(\mathrm{Biph}) \mathrm{Ph}_{2} \mathrm{TS}$ & $\mathrm{PdL}_{3}$ & \\
\hline $\mathrm{P}(\mathrm{Biph})_{2} \mathrm{PhTS}$ & $\mathrm{PdL}_{3}+\mathrm{PdL}_{2}$ & {$\left[\mathrm{PdL}_{2}\right]$ increase } \\
\hline $\mathrm{P}(\mathrm{Biph})_{3} \mathrm{TS}$ & $\mathrm{PdL}_{4}+\mathrm{PdL}_{3}$ & {$\left[\mathrm{PdL}_{3}\right]$ increase $+\mathrm{PdL}_{2}$ formed } \\
\hline
\end{tabular}

\subsection{Comparison of the Results Obtained with Palladium and Platinum Complexes}

An overview of the results is presented in Table 4 . 
Table 4. Effects of RAME- $\beta$-CD addition on the platinum and palladium complexes obtained with the different phosphanes (in $\mathrm{D}_{2} \mathrm{O}$, at $25^{\circ} \mathrm{C}$ ); $\mathrm{CD}=\mathrm{RAME}-\beta-\mathrm{CD} ; \mathrm{L} @ \mathrm{CD}=$ Ligand included in the $\mathrm{CD}$ cavity.

\begin{tabular}{|c|c|c|c|}
\hline Entry & Ligand (L) & Influence of CD on Pt Complexes & Influence of CD on Pd Complexes \\
\hline 1 & TPPTS & $\begin{array}{l}{\left[\mathrm{PtL}_{3} \mathrm{Cl}\right] \mathrm{Cl}+\mathrm{CD} \rightarrow \text { cis }-\mathrm{PtCl}_{2} \mathrm{~L}_{2}+\mathrm{L} @ \mathrm{CD}} \\
\mathrm{CD}=\text { decoordination promotor }\end{array}$ & $\mathrm{PdL}_{3}$ unchanged with $\mathrm{CD}$ \\
\hline 2 & $\begin{array}{l}\operatorname{tris}(p-\mathrm{Me}) \mathrm{TPPTS} \\
\operatorname{tris}(p \text {-OMe)TPPTS }\end{array}$ & {$\left[\mathrm{PtL}_{3} \mathrm{Cl}\right] \mathrm{Cl}$ unchanged with $\mathrm{CD}$} & $\mathrm{PdL}_{3}$ unchanged with $\mathrm{CD}$ \\
\hline 3 & $\begin{array}{l}\operatorname{tris}(o-\mathrm{Me}) \mathrm{TPPTS} \\
\operatorname{tris}(o-\mathrm{OMe}) \mathrm{TPPTS}\end{array}$ & $\begin{array}{l}{\left[\mathrm{PtL}_{3} \mathrm{Cl}\right] \mathrm{Cl} \text { impossible to obtain; }} \\
\text { trans }-\mathrm{PtCl}_{2} \mathrm{~L}_{2} \text { was formed } \\
\text { with or without } \mathrm{CD}\end{array}$ & $\begin{array}{l}\text { Ligand unable to extract Pd } \\
\text { from the organic layer } \\
\text { with or without } C D\end{array}$ \\
\hline 4 & $\mathrm{P}(\mathrm{Biph}) \mathrm{Ph}_{2} \mathrm{TS}$ & $\begin{array}{l}{\left[\mathrm{PtL}_{3} \mathrm{Cl}\right] \mathrm{Cl}+\mathrm{CD} \rightarrow\left[(\mathrm{L} @ \mathrm{CD}) \mathrm{PtL}_{2} \mathrm{Cl}\right] \mathrm{Cl}} \\
\mathrm{CD}=\text { second sphere ligand }\end{array}$ & $\begin{array}{l}\mathrm{PdL}_{3}+\mathrm{CD} \rightarrow(\mathrm{L} @ \mathrm{CD}) \mathrm{PdL}_{2} \\
\mathrm{CD}=\text { second sphere ligand }\end{array}$ \\
\hline 5 & $\mathrm{P}(\mathrm{Biph})_{2} \mathrm{PhTS}$ & n.d. (broad signals with or without CD) & $\begin{array}{l}\mathrm{PdL}_{3}+\mathrm{CD} \rightarrow \mathrm{PdL}_{2}+\mathrm{L} @ \mathrm{CD} \\
\mathrm{L}^{*}=\mathrm{L} \text { or } \mathrm{L} @ \mathrm{CD} \\
\mathrm{CD}=\text { decoordination promotor } \\
\text { and second sphere ligand }\end{array}$ \\
\hline 6 & $\mathrm{P}(\mathrm{Biph})_{3} \mathrm{TS}$ & n.d. (broad signals with or without CD) & $\begin{array}{l}\mathrm{PdL}_{4}+\mathrm{CD} \rightarrow \mathrm{PdL}^{*}+\mathrm{L} @ \mathrm{CD} \\
\mathrm{PdL}^{*}{ }_{3}+\mathrm{CD} \rightarrow \mathrm{PdL}^{*}{ }_{2}+\mathrm{L} @ \mathrm{CD} \\
\mathrm{L}^{*}=\mathrm{L} \text { or } \mathrm{L} @ \mathrm{CD} \\
\mathrm{CD}=\text { decoordination promotor } \\
\text { and second sphere ligand }\end{array}$ \\
\hline
\end{tabular}

Firstly, tris-ortho-substituted hydrosoluble phosphanes led to low coordinated platinum species and are unable to extract palladium from a Pd(TPP) $)_{4}$ toluene solution (Table 4, entry 3). These two behaviours are probably due to the steric hindrance around their phosphorous atom making them poor ligands. Apart from this peculiar case and the results obtained with platinum for $\mathrm{P}(\mathrm{Biph})_{2} \mathrm{PhTS}$ and $\mathrm{P}(\mathrm{Biph})_{3} \mathrm{TS}$ ligands (broad signals in ${ }^{31} \mathrm{P}\left\{{ }^{1} \mathrm{H}\right\} \mathrm{NMR}$ ) (entries 5 and 6), three $\mathrm{CD}$ behaviours towards $\left[\mathrm{PtL}_{3} \mathrm{Cl}\right] \mathrm{Cl}$ and $\mathrm{PdL}_{\mathrm{n}}$ complexes were noticed:

- The CD can have no influence on the organometallic species. That is what is observed with para-substituted hydrosoluble phosphanes for both palladium and platinum complexes (entry 2) and also with TPPTS, only in the case of palladium (entry 1). For the para-substituted hydrosoluble phosphanes, this behaviour could be explained by the lack of interaction between the CD and the phosphane (tris( $p$-OMe)TPPTS), or by a too strong metal-phosphorus bond coming from a high $\sigma$-donor ligand (tris( $p$-Me)TPPTS). However, the fact that the $\mathrm{PdL}_{2}$ species is not formed after CD addition on the $\mathrm{PdL}_{3}$ complex not only for tris $(p$-OMe)TPPTS and tris $(p$-Me)TPPTS but also for TPPTS probably comes from the too unstable $\mathrm{PdL}_{2}\left(14 \mathrm{e}^{-}\right.$species) in the case of TPPTS derivatives.

- The CD can act as a phosphane decoordination promotor. This property was emphasised with TPPTS as ligand in the $\left[\mathrm{PtL}_{3} \mathrm{Cl}\right] \mathrm{Cl}$ complex (entry 1), and with $\mathrm{P}(\mathrm{Biph})_{2} \mathrm{PhTS}$ and $\mathrm{P}(\mathrm{Biph})_{3} \mathrm{TS}$ ligands in the case of $\mathrm{PdL}_{n}$ type complexes (entries 5 and 6). The fact that TPPTS can be removed from Pt by addition of CD, contrary to tris $(p$-OMe)TPPTS and tris( $p$-Me)TPPTS, comes not only from its ability to be included in the CD cavity but also to its lower coordination power (less basic ligand).

- The CD can act as a second sphere ligand by including the metal-bound phosphane. This property was undoubtedly highlighted for both platinum and palladium complexes with the $\mathrm{P}(\mathrm{Biph}) \mathrm{Ph}_{2} \mathrm{TS}$ ligand whose $p$-sodiosulfobiphenyl group is well recognized by the $C D$. Because of this identical group present in their structure, making them accessible for a cyclodextrin even when bound to a metal, it is also important to say that $\mathrm{P}(\mathrm{Biph})_{2} \mathrm{PhTS}$ and $\mathrm{P}(\mathrm{Biph})_{3} \mathrm{TS}$ based organometallic species form also surely supramolecular complexes with $C D$. This property plays probably a role in the observed decoordination of $\mathrm{P}(\mathrm{Biph})_{2} \mathrm{PhTS}$ and $\mathrm{P}(\mathrm{Biph})_{3} \mathrm{TS}$ from palladium, the $\mathrm{CD}$ being able to stabilize the low-coordinated resulting organometallic species. More concretely, this property can explain the observation of $\mathrm{PdL}_{2}$ type species when $\mathrm{P}(\mathrm{Biph})_{3} \mathrm{TS}$ ligand was used, species not formed with TPPTS ligand. Indeed, TPPTS structure doesn't permit complexation when bound to the metal. 
The three evoked behaviours of CD in the presence of a phosphane bound to a metal depend on different equilibria whose evolution is assumed to be under thermodynamic control. Indeed, in all the experiments conducted in this study, the temperature had always a reversible effect on the system. More concretely, the modification of spectra sometimes observed by heating disappeared systematically by recovering the room temperature.

Basically, by considering a simplified system consisting of a cyclodextrin (CD) and a phosphane (L ligand) coordinated to a metal (Met), i.e., a "Met $\leftarrow \mathrm{L}+\mathrm{CD}^{\prime}$ system, several evolutions are possible. Firstly, the phosphane can naturally leave the metal by decoordination and lead to a "Met $\square+\mathrm{L}+\mathrm{CD}$ " system (Scheme 7a,1). This last system can then be transformed by inclusion of the free ligand in the CD cavity (Scheme 7a, 2). Starting from the same initial system ("Met $\leftarrow \mathrm{L}+\mathrm{CD}^{\prime \prime}$ ), another evolution can be the complexation of ligand bound to the metal to reach a "Met $\leftarrow$ L@CD" system in which the $\mathrm{CD}$ acts as a second sphere ligand (Scheme 7a, 3). In this complex, the "L@CD" part constitutes a supramolecular ligand which can therefore also leave the metal to lead to a "Met $+\mathrm{L} @ \mathrm{CD}^{\prime}$ system (Scheme 7a, 4). The fore-mentioned systems are in equilibrium and their proportions are consequently driven by their free enthalpy, the more stable system being the more represented one.

So, when the "Met $\leftarrow$ L" starting organometallic species stays perfectly stable in the presence

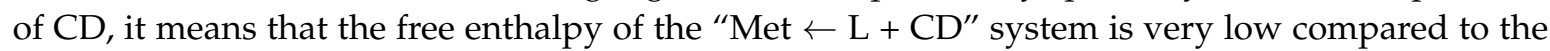
other possible systems (Scheme 7b). Different reasons can produce this situation: basicity of the ligand making the "Met $\leftarrow \mathrm{L}$ " bond very strong, ligand poorly recognized by the CD...

In the same way, when $C D$ is proved to be a decoordination promotor by being able to do an inclusion complex with the phosphane, it means that the "Met $\mathrm{L}+\mathrm{L} @ \mathrm{CD}^{\prime}$ " system is relatively close to the "Met $\leftarrow \mathrm{L}+\mathrm{CD}^{\prime}$ initial system, in terms of free enthalpy (Scheme 7(c)). In this case, the "Met $+\mathrm{L} @ C \mathrm{CD}^{\prime}$ system can be reached either by preliminary natural decoordination of the phosphane via the "Met $[+\mathrm{L}+\mathrm{CD}$ " system (Scheme 7(c)), mechanism with the successive steps 1 and 2) or by preliminary complexation of the organometallic species by the CD (Scheme 7(c), mechanism with steps 3 and 4 successively). This second mechanism is probably favoured when the CD is able to include the ligand bound to the metal, i.e., when the free enthalpy of the Met $\leftarrow$ L@CD is low. Therefore, one can think that TPPTS decoordination from $\left[\mathrm{PtL}_{3} \mathrm{Cl}\right] \mathrm{Cl}$ species by $\mathrm{CD}$ proceed via the " 1,2 " mechanism (Met $\leftarrow$ L@CD species is too high in free enthalpy to be easily reached in the case of TPPTS) and that biphenyl phosphanes decoordination from palladium species proceed by the " 3,4 " mechanism (Met $\leftarrow$ L@CD is easy to form).

Finally, the "Met $\leftarrow$ L@CD" species can be obtained from the initial "Met $\leftarrow \mathrm{L}+\mathrm{CD}$ " system via direct complexation (scheme $7(\mathrm{~d})$, step 3) or via preliminary formation of the "L@CD" inclusion complex in solution (Scheme 7(d), steps 1, 2 and -4).

The simple rationalization of the different transformations observed in this study for platinum and palladium complexes in the presence of RAME- $\beta$-CD can be refined by taking into account the fact that several ligands are systematically present on the metal. In particular, for ligands allowing a complexation by CD when coordinated to the metal (biphenyl phosphanes, in this study), relatively stable organometallic species possessing two spheres of coordination (phosphane and CD, respectively) may be obtained. However, in these species, the steric hindrance generated by the complexation by the CD constitutes a possible reason explaining that the included ligand or a neighbour ligand can be expulsed to reach a more stable system (Scheme 8, pathway (a)).

Conversely, for ligands not accessible for a CD when bound to a metal (TPPTS, in this study), the only way to explain an observed decoordination in the presence of CD is undoubtedly the preliminary decoordination of the ligand from the metal (Scheme 8, pathway (b)). 


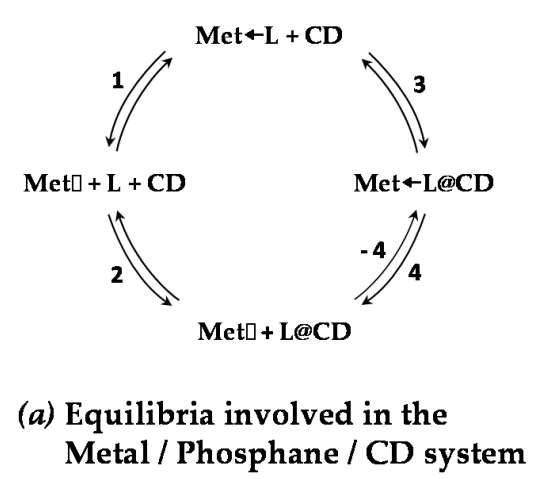

\section{Metal / Phosphane / CD system}

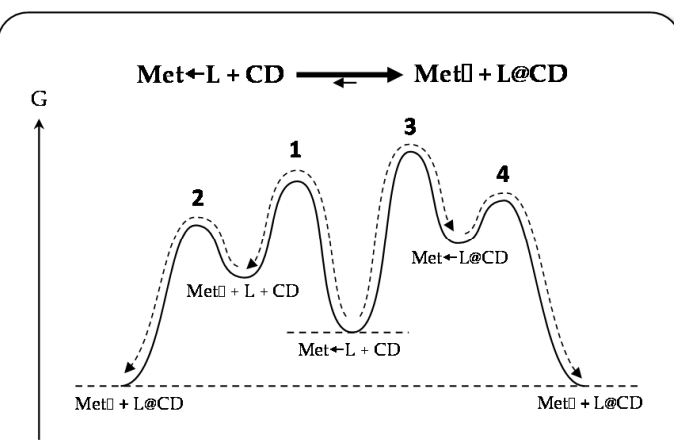

1, 2 : Mechanism via preliminary decoordination of $\mathrm{L}$ ligand 3, 4 : Mechanism via complexation of Met $\leftarrow$ L species by CD

(c) $\mathrm{CD}$ as decoordination promotor

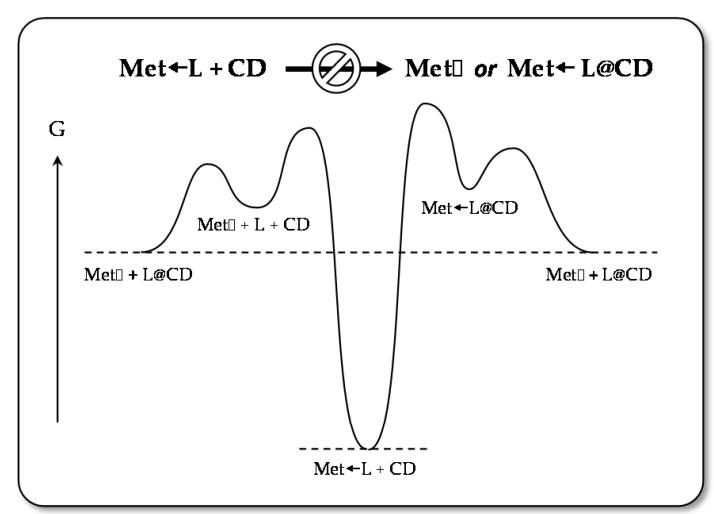

(b) CD with no influence

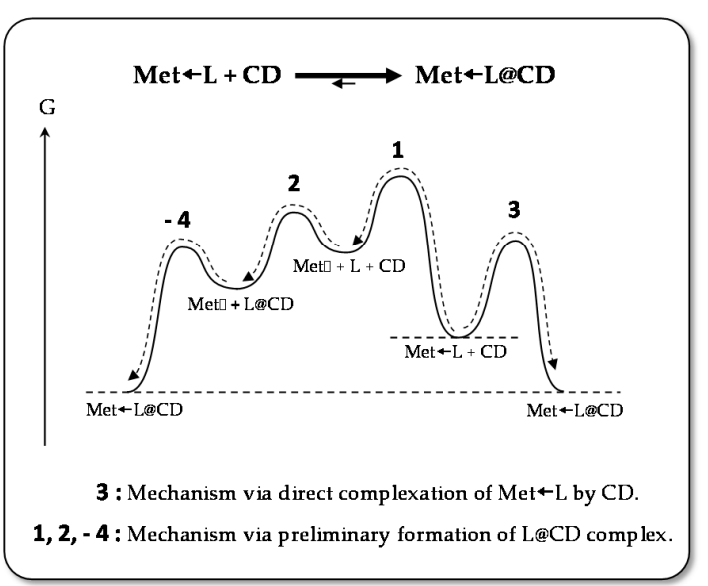

(d) $\mathrm{CD}$ as second sphere ligand

Scheme 7. Different possible mechanisms for the cyclodextrin assisted generation of new organometallic species from a metal coordinated by a ligand (Met $\leftarrow$ L species); Met $=$ metal, $\mathrm{L}=$ Phosphane, $\mathrm{L} @ \mathrm{CD}=$ ligand included in the CD cavity.

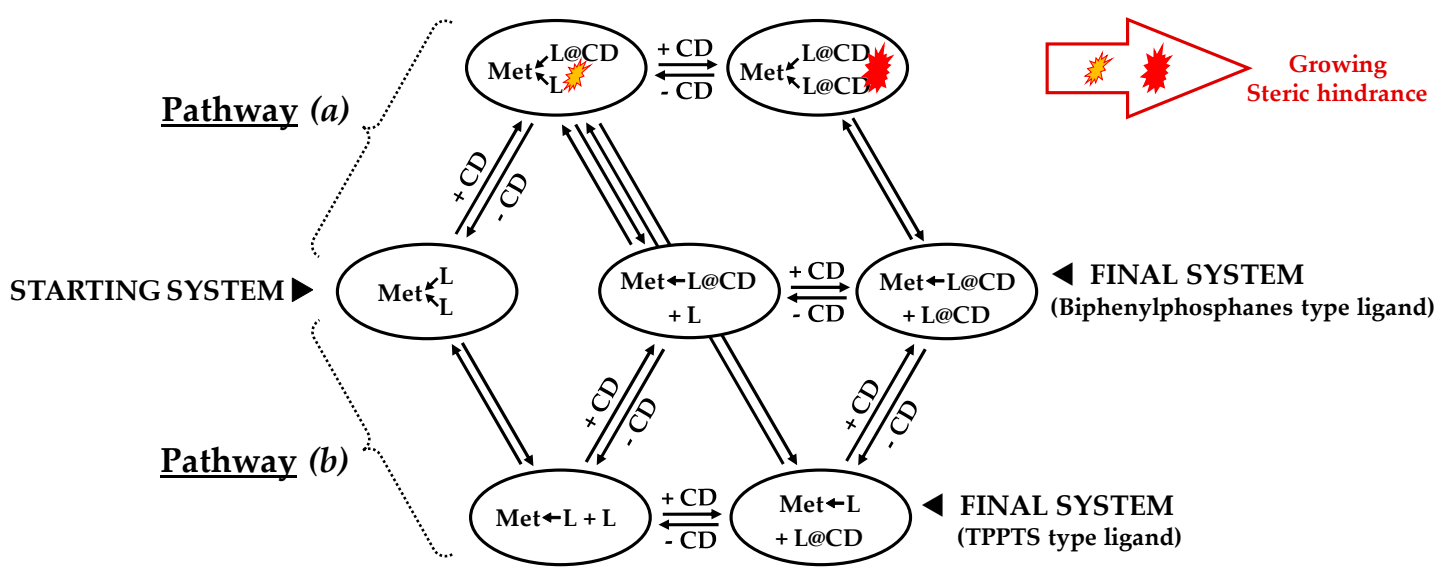

Scheme 8. Two possible pathways of generation of low coordinated organometallic species thanks to a cyclodextrin from a species bearing several ligands (symbolized by "MetL 2 "): (a) via supramolecular organometallic species; (b) via preliminary decoordination of a ligand; Met = metal, L = Phosphane, $\mathrm{L} @ \mathrm{CD}=$ ligand included in the CD cavity. 


\section{Materials and Methods}

\subsection{General Remarks}

The ${ }^{1} \mathrm{H}$ and ${ }^{31} \mathrm{P}\left\{{ }^{1} \mathrm{H}\right\}$ NMR spectra were recorded on an Avance 300 DPX instrument (Bruker, Karlsruhe, Germany) at 300.13 and $121.49 \mathrm{MHz}$, respectively. Organic compounds were purchased from Fisher Scientific (Pittsburgh, PA, USA) in their highest purity and used without further purification. Potassium tetrachloroplatinate(II) and tetrakis(triphenylphosphane)palladium(0) were purchased from Strem Chemicals (Newburyport, MA, USA). Ultrapure water was used in all experiments (Fresenius Kabi, Bad Homburg, Germany; $\gamma=72.0 \mathrm{mN} \cdot \mathrm{m}^{-1}$ at $25{ }^{\circ} \mathrm{C}$ ). Pharmaceutical grade RAME- $\beta$-CD (Cavasol ${ }^{\circledR}$ W7 M) was purchased from Wacker Chemie GmbH (München, Germany) and was used as received. Randomly methylated $\beta$-cyclodextrin (RAME- $\beta-C D$ ) is a partially methylated cyclodextrin and its degree of substitution was equal to 1.8 (1.8 methyl groups per glucopyranose unit). TPPTS [24], tris(o-Me)TPPTS [25], tris(o-OMe)TPPTS [25], tris( $p$-Me)TPPTS [15] and tris $(p-\mathrm{OMe})$ TPPTS [26], $\mathrm{P}(\mathrm{Biph}) \mathrm{Ph}_{2}$ TS [16], $\mathrm{P}(\mathrm{Biph})_{2} \mathrm{PhTS}$ [16] and $\mathrm{P}(\mathrm{Biph})_{3}$ TS [16] were prepared as reported in the literature. The purity of these water-soluble phosphanes was controlled by ${ }^{1} \mathrm{H}$, ${ }^{13} \mathrm{C}\left\{{ }^{1} \mathrm{H}\right\}$ and ${ }^{31} \mathrm{P}\left\{{ }^{1} \mathrm{H}\right\}$ NMR analysis.

\section{2. ${ }^{31} P\left\{{ }^{1} H\right\} N M R$ Study on Platinum and Palladium Complexes}

Platinum complexes were synthetized by dissolving $\mathrm{K}_{2} \mathrm{PtCl}_{4}(8.3 \mathrm{mg}, 0.02 \mathrm{mmol})$ in degassed deuterated water $(2 \mathrm{~mL})$. Three equiv. of the corresponding ligand $(0.06 \mathrm{mmol})$ were added to the solution, which was then stirred for $15 \mathrm{~min}$ at room temperature under nitrogen. Studies in the presence of RAME- $\beta-C D$ were conducted as follows: the required amount of cyclodextrin was introduced into $500 \mu \mathrm{L}$ of the above solution. After $15 \mathrm{~min}$ of stirring, the solution was transferred into a NMR tube and analysed.

Palladium complexes were synthetized according to a modified literature procedure [27]. $\mathrm{Pd}\left(\mathrm{PPh}_{3}\right)_{4}$ (103 mg, $0.089 \mathrm{mmol}$.) was dissolved in $2 \mathrm{~g}$ of degassed toluene into a Schlenk tube under nitrogen. The corresponding phosphane (1.5 equiv., $0.133 \mathrm{mmol}$ ) was dissolved in $2 \mathrm{~g}$ of $\mathrm{D}_{2} \mathrm{O}$ and cannulated onto the palladium solution. The mixture was stirred for $30 \mathrm{~min}$ at room temperature. After decantation, the organic phase was removed and a new degassed $\mathrm{Pd}\left(\mathrm{PPh}_{3}\right)_{4}$ solution was added to the previous aqueous solution which underwent again a 30 min stirring period to ensure an optimal extraction of the palladium by the hydrosoluble ligand. After decantation, the aqueous phase was recovered. The obtained $\mathrm{PdL}_{n}(n=2,3$ or 4$)$ solution was then used for the ${ }^{31} \mathrm{P}\left\{{ }^{1} \mathrm{H}\right\} \mathrm{NMR}$ study. The previous solution usually contained a small excess of free ligand. Study in the presence of RAME- $\beta$-CD was conducted as follow: to $1 \mathrm{~mL}$ of the above solution was introduced under nitrogen the required amount of RAME- $\beta$-CD. After 15 min of stirring, the solution was transferred via cannula into a nitrogen pressurized $5 \mathrm{~mm}$ NMR tube.

\section{Conclusions}

A ${ }^{31} \mathrm{P}\left\{{ }^{1} \mathrm{H}\right\}$ NMR study of platinum(II) and palladium(0) complexes coordinated with two different groups of hydrosoluble monodentate phosphane ligands (including TPPTS, meta-trisulfonated triphenylphosphane derivatives bearing one methyl (or methoxy) group on the aromatic ring and trisulfonated biphenylphosphanes) has been described. The effect of randomly methylated $\beta$-cyclodextrin (RAME- $\beta$-CD) addition on these complexes has been examined.

It has been shown that the interaction of the free phosphane with RAME- $\beta-C D$ is a prerequisite to observe any effect of the CD on the organometallic species (case of tris( $p$-OMe)TPPTS: no interaction, thus no effect). However, the stereoelectronic properties of the ligand are also of great importance. On the one hand, ligands whose phosphorous atom is hindered by ortho-substituted meta-sulfophenyl groups lead, without CD, to low coordinated organometallic species, even with an excess of ligand; the lack of free volume in the coordination sphere of these species doesn't permit the coordination of another ligand (case of tris(o-Me)TPPTS and tris(o-OMe)TPPTS, with platinum). On the other hand, 
a high $\sigma$-donating ligand can be difficult to be removed from the metal by $\mathrm{CD}$ because of the stability of its metal-phosphorous bond (case of tris( $p$-Me)TPPTS, with platinum as well as palladium).

More generally, two interesting behaviours of $C D$ have been highlighted: the $C D$ can act as a second sphere ligand by including the metal-bound phosphane without denaturing the organometallic species or as a phosphane decoordination promotor. These two behaviours are under thermodynamic control. Depending on the used ligand structure, the decoordination observed in the presence of $\mathrm{CD}$ may proceed either via a preliminary decoordination of the phosphane followed by a complexation of the free ligand by the CD (case of TPPTS) or via the generation of organometallic species complexed by $C D$ which then lead to expulsion of ligands to decrease their internal steric hindrance (cases of biphenylphosphanes).

Such modifications of organometallic complexes by a CD, i.e., inclusion of organometallic species into the cyclodextrin cavity by one of its ligand or decoordination of a ligand from the metal, can be efficient strategies to obtain new catalysts possessing original activities and selectivities.

Supplementary Materials: The following are available online at http://www.mdpi.com/1420-3049/22/1/140/s1: Figures S1-S12.

Acknowledgments: This work was supported by the Centre National de la Recherche Scientifique (CNRS). M. Ferreira is grateful to the Ministère de l'Education et de la Recherche for financial support (2005-2008).

Author Contributions: M.F. performed the experiments; M.F., H.B., S.T. and E.M. analyzed the data and wrote the paper.

Conflicts of Interest: The authors declare no conflict of interest.

\section{References and Notes}

1. Dixneuf, P.H.; Cadierno, V. Metal-Catalyzed Reactions in Water; Wiley-VCH: Weinheim, Germany, 2013.

2. Cornils, B.; Hermann, W.A. Aqueous-Phase Organometallic Catalysis; Wiley-VCH: Weinheim, Germany, 2004.

3. Shaughnessy, K.H. Hydrophilic ligands and their application in aqueous-phase metal-catalyzed reactions. Chem. Rev. 2009, 109, 643-710. [CrossRef] [PubMed]

4. Cornils, B.; Kuntz, E.G. Introducing TPPTS and related ligands for industrial biphasic processes. J. Organomet. Chem. 1995, 502, 177-186. [CrossRef]

5. Obrecht, L.; Kamer, P.C.J.; Laan, W. Alternative approaches for the aqueous-organic biphasic hydroformylation of higher alkenes. Catal. Sci. Technol. 2013, 3, 541-551. [CrossRef]

6. Sharma, S.K.; Jasra, R.V. Aqueous phase catalytic hydroformylation reactions of alkenes. Catal. Today 2015, 247, 70-81. [CrossRef]

7. Hapiot, F.; Ponchel, A.; Tilloy, S.; Monflier, E. Cyclodextrins and their applications in aqueous-phase metal-catalyzed reactions. C. R. Chim. 2011, 14, 149-166. [CrossRef]

8. Hapiot, F.; Bricout, H.; Menuel, S.; Tilloy, S.; Monflier, E. Recent breakthroughs in aqueous cyclodextrin-assisted supramolecular catalysis. Catal. Sci. Technol. 2014, 4, 1899-1908. [CrossRef]

9. Mathivet, T.; Méliet, C.; Castanet, Y.; Mortreux, A.; Caron, L.; Tilloy, S.; Monflier, E. Rhodium catalyzed hydroformylation of water insoluble olefins in the presence of chemically modified $\beta$-cyclodextrins: Evidence for ligand-cyclodextrin interactions and effect of various parameters on the activity and the aldehydes selectivity. J. Mol. Catal. A Chem. 2001, 176, 105-116. [CrossRef]

10. Monflier, E.; Bricout, H.; Hapiot, F.; Tilloy, S.; Aghmiz, A.; Masdeu-bultó, A.M. High-Pressure ${ }^{31} \mathrm{P}\left\{{ }^{1} \mathrm{H}\right\} \mathrm{NMR}$ Studies of $\mathrm{RhH}(\mathrm{CO})(\mathrm{TPPTS})_{3}$ in the presence of methylated cyclodextrins: New light on rhodium-catalyzed hydroformylation reaction assisted by cyclodextrins. Adv. Synth. Catal. 2004, 346, 425-431. [CrossRef]

11. Caron, L.; Canipelle, M.; Tilloy, S.; Bricout, H.; Monflier, E. Unexpected effect of cyclodextrins on water-soluble rhodium complexes. Eur. J. Inorg. Chem. 2003, 4, 595-599. [CrossRef]

12. Binkowski-Machut, C.; Canipelle, M.; Bricout, H.; Tilloy, S.; Hapiot, F.; Monflier, E. Supramolecular trapping of phosphanes by cyclodextrins: A general approach to generate phosphane coordinatively unsaturated organometallic complexes. Eur. J. Inorg. Chem. 2006, 2006, 1611-1619. [CrossRef]

13. Caron, L.; Bricout, H.; Tilloy, S.; Ponchel, A.; Landy, D.; Fourmentin, S.; Monflier, E. Molecular recognition between a water-soluble organometallic complex and a $\beta$-cyclodextrin: First example of second-sphere coordination adducts possessing a catalytic activity. Adv. Synth. Catal. 2004, 346, 1449-1456. [CrossRef] 
14. Leclercq, L.; Schmitzer, A.R. Assembly of tunable supramolecular organometallic catalysts with cyclodextrins. Organometallics 2010, 29, 3442-3449. [CrossRef]

15. Ferreira, M.; Bricout, H.; Sayede, A.; Ponchel, A.; Fourmentin, S.; Tilloy, S.; Monflier, E. Biphasic aqueous organometallic catalysis promoted by cyclodextrins: How to design the water-soluble phenylphosphane to avoid interaction with cyclodextrin. Adv. Synth. Catal. 2008, 350, 609-618. [CrossRef]

16. Ferreira, M.; Bricout, H.; Hapiot, F.; Sayede, A.; Tilloy, S.; Monflier, E. A property-matched water-soluble analogue of the benchmark ligand $\mathrm{PPh}_{3}$. ChemSusChem 2008, 1, 631-636. [CrossRef] [PubMed]

17. Francisco, L.W.; Moreno, D.A.; Atwood, J.D. Synthesis, characterization, and reaction chemistry of $\mathrm{PtCl}_{2}\left[\mathrm{P}\left(m-\mathrm{C}_{6} \mathrm{H}_{4} \mathrm{SO}_{3} \mathrm{Na}\right)_{3}\right]_{2}$, an Alkyne hydration catalyst. Organometallics 2001, 20, 4237-4245. [CrossRef]

18. Snelders, D.J.M.; van Koten, G.; Klein Gebbink, R.J.M. Steric, electronic, and secondary effects on the coordination chemistry of ionic phosphine ligands and the catalytic behavior of their metal complexes. Chemistry 2011, 17, 42-57. [CrossRef] [PubMed]

19. Binkowski, C.; Cabou, J.; Bricout, H.; Hapiot, F.; Monflier, E. Cleavage of water-insoluble alkylallylcarbonates catalysed by a palladium/TPPTS/cyclodextrin system: Effect of phosphine/cyclodextrin interactions on the reaction rate. J. Mol. Catal. A Chem. 2004, 215, 23-32. [CrossRef]

20. Sayede, A.; Ferreira, M.; Bricout, H.; Tilloy, S.; Monflier, E. Interaction of water-soluble triphenylphosphines with $\beta$-cyclodextrin: A quantum chemistry study. J. Phys. Org. Chem. 2011, 24, 1129-1135. [CrossRef]

21. In preliminary experiments, the formation of $c i s-\mathrm{PtCl}_{2}(\operatorname{tris}(p-\mathrm{Me}) \mathrm{TPPTS})_{2}$ and $c i s-\mathrm{PtCl}_{2}(\operatorname{tris}(p-\mathrm{OMe}) \mathrm{TPPTS})_{2}$ was evidenced by mixing 2 equiv. of the corresponding ligand to a $\mathrm{K}_{2} \mathrm{PtCl}_{4}$ aqueous solution (see ESI).

22. Native $\beta$-CD was used for the convenience of understanding the ${ }^{1} \mathrm{H}-\mathrm{NMR}$ signals compared to RAME- $\beta$-CD which shows overlapping non-interpretable resonances.

23. Monteil, F.; Kalck, P. Carbonylation of bromobenzene in a biphasic medium catalysed by water-soluble palladium complexes derived from tris(3-sulphophenyl)phosphine. J. Organomet. Chem. 1994, 482, 45-51. [CrossRef]

24. Gärtner, R.; Cornils, B.; Springer, H.; Lappe, P. Process for the Preparation of Sulfonated Aryl Phosphine. U.S. Patent 4,483,802, 20 November 1984.

25. Herrmann, W.A.; Albanese, G.P.; Manetsberger, R.B.; Lappe, P.; Bahrmann, H. New process for the sulfonation of phosphane ligands for catalysts. Angew. Chem. Int. Ed. Engl. 1995, 34, 811-813. [CrossRef]

26. Gulyás, H.; Szöllősy, Á.; Szabó, P.; Halmos, P.; Bakos, J. Preparation of new sulfonated triarylphosphanes: Control of the selectivity by structural assistance. Eur. J. Org. Chem. 2003, 2003, 2775-2781. [CrossRef]

27. Herrmann, W.A.; Kellner, J.; Riepl, H. Wasserlösliche Metallkomplexe und Katalysatoren III. Neue wasserlösliche Metallkomplexe des sulfonierten Triphenylphosphans (TPPTS): Mn, Fe, Ru, Co, Rh, Ir, Ni, Pd, Pt, Ag, Au. J. Organomet. Chem. 1990, 389, 103-128. [CrossRef]

Sample Availability: Samples of the water-soluble phosphanes are available from the authors.

(c) 2017 by the authors; licensee MDPI, Basel, Switzerland. This article is an open access article distributed under the terms and conditions of the Creative Commons Attribution (CC-BY) license (http://creativecommons.org/licenses/by/4.0/). 